\title{
Future changes of El Niño in two global coupled climate models
}

Received: 30 May 2005/ Accepted: 14 November 2005/Published online: 24 January 2006

(C) Springer-Verlag 2006

\begin{abstract}
Idealized forcing experiments with 1\% per year $\mathrm{CO}_{2}$ increase to stabilized doubled and quadrupled $\mathrm{CO}_{2}$, twenty-first century transient scenario experiments (SRES scenarios A1B and B1), and stabilized twentysecond century A1B and B1 experiments with two global coupled climate models (PCM and CCSM3) are analyzed for possible future changes of El Niño events. With increased $\mathrm{CO}_{2}$ in the models, there is a reduction of amplitude of $\mathrm{El}$ Niño events. This is particularly apparent with larger forcing in the stabilized $4 \times \mathrm{CO}_{2}$ experiment in PCM and the stabilized greenhouse gas A1B experiment in CCSM3, where the reduction of amplitude is outside the range of the inherent multicentury variability of El Niño in the control runs of the models and is statistically significant. With moderately increased forcing (stabilized $2 \times \mathrm{CO}_{2}$ in PCM and the stabilized $\mathrm{B} 1$ experiment in CCSM3), the reduction in amplitude is evident, but it is not significant. The change in El Niño behavior with larger forcing is attributed to the change in base state temperature in the equatorial Pacific, which is similar with increased greenhouse gases (GHGs) in both models. Positive temperature anomalies in and below the thermocline, associated with a reduction of the trade winds, and weakened Pacific Ocean subtropical cells, produce a less intense thermocline, and consequently lower amplitude El Niño events. The previously noted intensification of El Niño tropical precipitation anomalies in a warmer mean base state that applied when there was no appreciable change in El Niño amplitude does not hold in the present study where the El Niño events decrease in magnitude in a future warmer climate. North American surface temperature anomalies associated with El Niño are reduced and become less significant in the future events, with the anomalously deepened Aleutian low in the North Pacific
\end{abstract}

G. A. Meehl $(\bowtie) \cdot H$. Teng $\cdot$ G. Branstator

National Center for Atmospheric Research, PO Box 3000, Boulder CO, 80307 USA

E-mail: meehl@ncar.ucar.edu

Fax: 303-4971333 weakened and moved eastward with greater radiative forcing. Part of this is attributed to the smaller amplitude events and thus lower amplitude teleconnections as indicated by contrasting composites of medium and high amplitude El Niño events from the control runs. The change in midlatitude base state circulation also contributes to the change in El Niño teleconnections. The effects of this change in base state on the weakened El Niño teleconnections over North America are confirmed in sensitivity experiments with a version of the atmospheric model in which heating anomalies are specified to mimic El Niño events in a base state changed due to increased GHGs.

\section{Introduction}

Previous studies have shown that warming of base state temperatures in the upper layers of the tropical Pacific could possibly affect El Niño behavior in a warmer climate. Some studies have shown there is the possibility for larger amplitude El Niño events in the future (Timmermann et al. 1999; Collins 2000a, b; Cubasch et al. 2001; Chen et al. 2005; Guilyardi 2005). However, there appears to be a model-dependence to future changes of El Niño, with some models showing larger amplitude events, some showing smaller amplitude events, and some showing little change (Collins 2000b; Merryfield 2006; Guilyardi 2005; van Oldenborgh et al. 2005). It also has been noted that with the changes of base state midlatitude atmospheric circulation, the teleconnections associated with El Niño events could be different in a future warmer climate (Meehl et al. 1993).

However, with any study examining possible future changes of El Niño or El Niño teleconnections, sampling is a significant issue since there is considerable low frequency modulation of El Niño amplitude and frequency on multi-decadal timescales in observations and models 
(e.g. Knutson and Manabe 1998), and detecting changes of El Niño in a changing base state is a genuine challenge (Timmermann 1999). There are also differences in how the models simulate El Niño events in present-day climate (e.g. Achutarao and Sperber 2006; Capotondi et al. 2006; Guilyardi et al. 2004; Guilyardi 2005; Joseph and Nigam 2006). Therefore, physical arguments have been made in the studies cited above to try and explain possible future changes of El Niño.

Unfortunately, the sampling issues are not easily circumvented, and this will make any detection/attribution of changes of El Niño in a real-time evolving climate extremely difficult. But we can identify physical processes that could act to affect future El Niño events, and then look for these features in transient climate simulations and observations. We can also use ensembles of model simulations to identify quantitative relationships between present-day physical processes and future change, and then use those relationships to define the most likely outcome.

The purpose of the present paper is to analyze changes of El Niño in terms of amplitude and frequency using two global coupled climate models. The Parallel Climate Model (PCM) and the Community Climate System Model version 3 (CCSM3) have been shown to simulate El Niño reasonably well (Meehl et al. 2001; Deser et al. 2006). Additionally, we will present documentation of El Niño simulation features compared to observations in this paper (e.g. Figs. 1,3). The analysis of some aspects of El Niño shows that the CCSM3, in addition to being too biennial, has a marked SST mode whereas the observations show a hybrid mode with lower frequency (Guilyardi 2005).

To address the sampling issue, idealized forcing experiments will be analyzed with 100 year periods of stabilized idealized forcing for $2 \times$ and $4 \times \mathrm{CO}_{2}$ for the PCM. A 1,200 year segment from a PCM control run and a 500 year control run with CCSM3 will also be analyzed to provide estimates of multi-decadal variability of El Niño. Additionally, scenario simulations for twenty-first and twenty-second century climate will be analyzed for both models. A low forcing scenario (B1) and a medium forcing scenario (A1B) have been run for both models from 2000 to 2100 (Meehl et al. 2005). Stabilization scenarios also have been performed, one with all concentrations fixed at year 2000 values for the subsequent 100 years (twentieth century stabilization), and another two with concentrations fixed at year 2100 values for B1 and A1B, respectively, and run for another 100 years each.

Section 2 includes a description of the models and the experiments. Section 3 looks at the changes of amplitude and frequency of El Niño in the increased GHG simulations, and compares those changes to inherent multidecadal variability in the models. Section 4 examines possible reasons for those changes, and Sect. 5 looks at changes in midlatitude teleconnections associated with El Niño events in a future warmer climate. Section 6 presents conclusions.

\section{Model description and experiments}

We use two global coupled climate models with components of atmosphere, ocean, dynamic sea ice, and land surface. One is the PCM described by Washington et al. (2000) and used in the climate change studies of Ammann et al. (2003), Meehl et al. (2003, 2004a, b), Santer et al. (2003a, b), Meehl et al. (2005), and others. The resolution of the atmosphere is T42, or roughly $2.8 \times 2.8^{\circ}$, with 18 levels in the vertical. Resolution in the midlatitude ocean is roughly $0.67^{\circ}$ decreasing to $0.5^{\circ}$ in the equatorial tropics, with 32 levels. No flux adjustments are used in the model, and, at least in terms of globalmean surface temperature, a relatively stable climate is simulated. For example, the last 1,200 years of a 1,500year long pre-industrial (1870) control integration show only a small cooling trend of globally averaged surface air temperature of roughly $0.03 \mathrm{~K}$ per century (Dai et al. 2005). The amplitude of interannual climate variability related to ENSO is in reasonably good agreement with observations (Meehl et al. 2001; Dai et al. 2001), and other circulation features are well-simulated (Arblaster and Meehl 2006).

In addition to the pre-industrial control run mentioned above, a branch run starting from early in a present-day control run with $\mathrm{CO}_{2}$ increasing $1 \%$ per year compounded annually has been integrated with the PCM. At $2 \times \mathrm{CO}_{2}$ and $4 \times \mathrm{CO}_{2}$, this branch run is integrated for an additional 150 years respectively with $\mathrm{CO}_{2}$ concentrations held constant at those amounts. This provides a stable forcing environment within which to analyze changes in El Niño, and the last 100 years from those simulations are analyzed (e.g. as in the monsoon analyses of Meehl and Arblaster 2003). There is small amplitude warming during these time periods, but it is relatively slight 50 years after stabilization (Washington et al. 2000).

The CCSM3 is the second global coupled climate model analyzed here and is described in detail in Collins et al. (2006). In this paper we describe results from the T85 version of CCSM3, with grid points in the atmosphere roughly every $1.4^{\circ}$ latitude and longitude, and 26 levels in the vertical. The ocean is a version of POP with a nominal latitude-longitude resolution of $1^{\circ}\left(0.5^{\circ} \mathrm{Eq}\right.$. Tropics) and 40 levels in the vertical, with GentMcWilliams and KPP mixing (Collins et al. 2006). The land surface model is the Community Land Model (CLM, Dickinson et al. 2006), and the EVP dynamic and thermodynamic sea ice component is the CSIM4 (Holland et al. 2006). No flux adjustments are used in the CCSM3. An 1870 control run has been continued for over 500 years with this model, and in this experiment El Niño variability resembles many aspects of the observations (Deser et al. 2006).

The multi-member ensemble twentieth century simulations for both models have been started from different times in their pre-industrial control runs, usually separated by 20 years. Forcings included natural 
a) PCM control

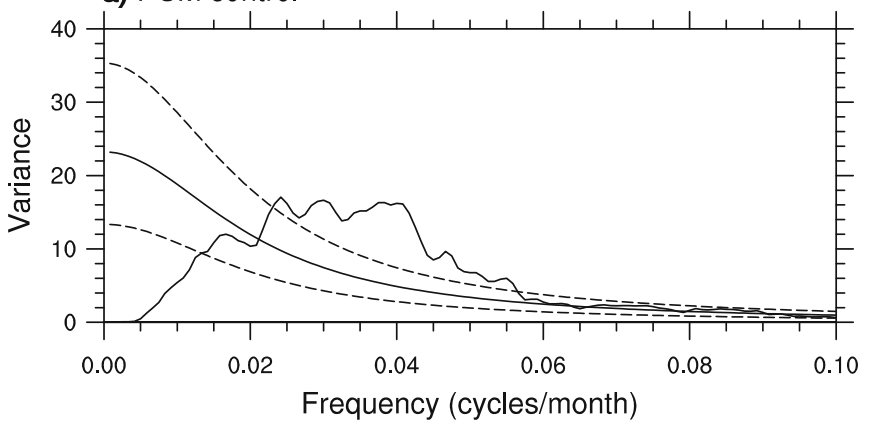

c) $\mathrm{PCM} 2 \mathrm{XC02}$

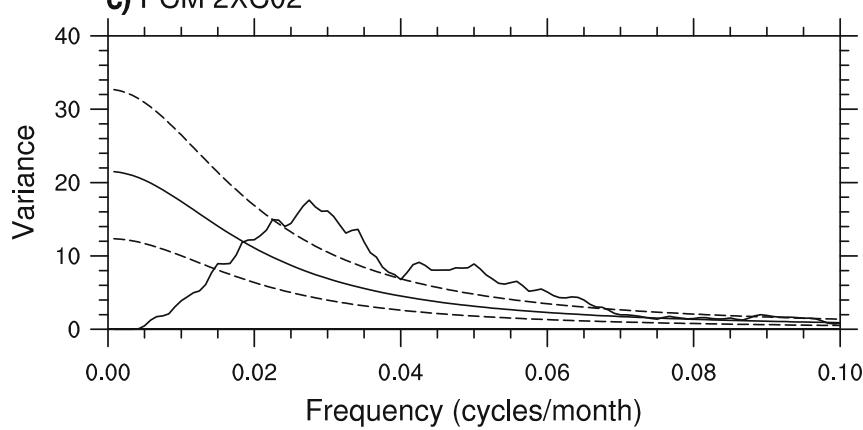

e) PCM 4XC02

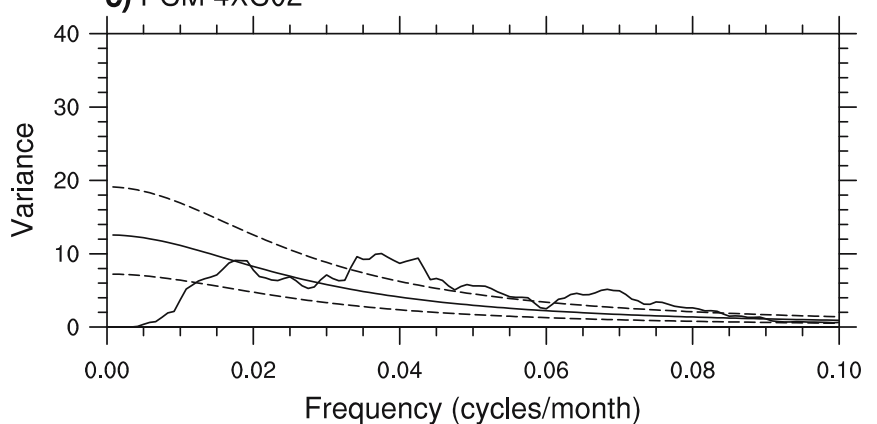

Fig. 1 a Power spectra of Niño3.4 time series from a 100 year period in the PCM control run. b Same as (a) except for the CCSM3 twentieth century stabilization experiment. c Same as (a) except for the PCM $2 \times \mathrm{CO}_{2}$ experiment. d Same as (a) except for the

(volcanoes and solar) and anthropogenic (GHGs, sulfate aerosols, and ozone) sources. They are used as the initial conditions for two twenty-first century SRES scenario simulations labeled $\mathrm{B} 1$ (low forcing, for example, $\mathrm{CO}_{2}$ increases to $550 \mathrm{ppm}$ or about $150 \%$ of the year 2000 value, $1.50 \times \mathrm{CO}_{2}$ ), and $\mathrm{A} 1 \mathrm{~B}$ (medium forcing, for example, $\mathrm{CO}_{2}$ increases to $690 \mathrm{ppm}$ or about $189 \%$ of the year 2000 value, $\left.1.89 \times \mathrm{CO}_{2}\right)$. The first stabilized experiment specified concentrations of all atmospheric constituents held fixed at year 2000 values, and the models were integrated for 100 years with these stabilized concentrations (stabilized twentieth century simulations). In the other stabilization experiments, concentrations for the $\mathrm{A} 1 \mathrm{~B}$ and $\mathrm{B} 1$ simulations were held fixed at year 2100 values, and the models were integrated to the year 2300 (stabilized B1 and A1B simulations; for details, see Meehl et al. 2006). All model b) CCSM3 20thC Stabilization

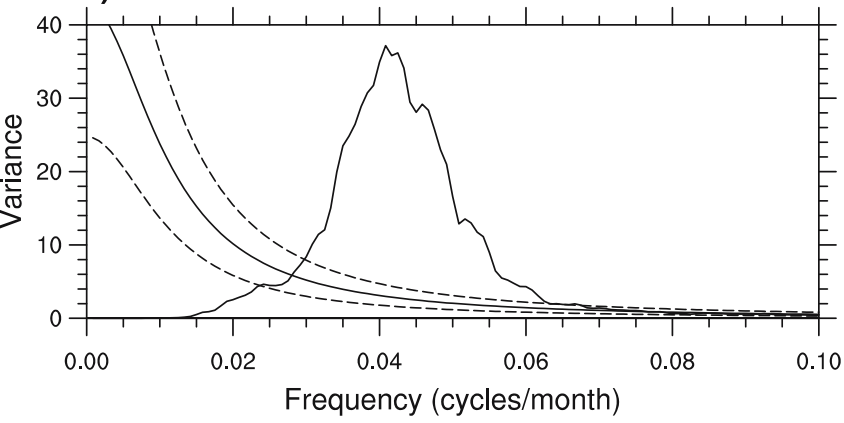

d) CCSM3 Stabilized_B1

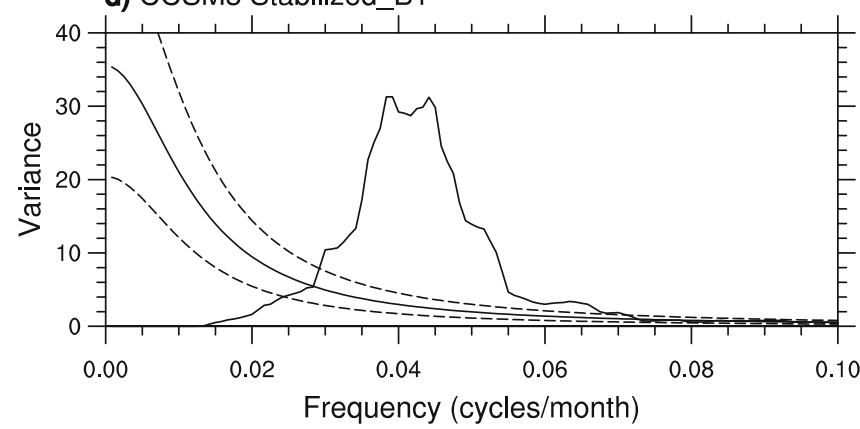

f) CCSM3 Stabilized_A1B

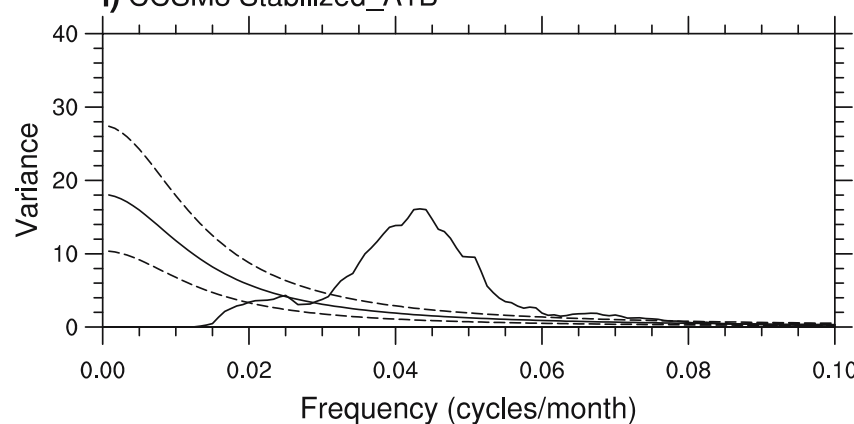

CCSM3 stabilized B1 experiment. e Same as (a) except for the PCM $4 \times \mathrm{CO}_{2}$ experiment. f Same as (a) except for the CCSM3 stabilized A1B experiment

simulations analyzed here are available from: http:// www-pcmdi.llnl.gov/ipcc/about_ipcc.php.

Throughout this study, we will use standard deviations of 1-5 year bandpass filtered Niño3.4 (averaged SSTs in the area $5^{\circ} \mathrm{N}-5^{\circ} \mathrm{S}, 170^{\circ} \mathrm{W}-120^{\circ} \mathrm{W}$ ) as the indicator of El Niño amplitude.

\section{Changes of El Niño in the models}

Figure 1 shows power spectra of Niño3.4 SST from 100 year periods in the control run, $2 \times \mathrm{CO}_{2}$ and $4 \times \mathrm{CO}_{2}$ experiments for PCM, and for the twentieth century stabilization, stabilized $\mathrm{B} 1$ and stabilized A1B experiments for the CCSM3. As documented earlier for these models, power is concentrated towards the higher ENSO frequencies from 2 to 4 years, as compared to 
Fig. 2 a Time series of detrended standard deviation of band-pass filtered (1-5 years) Niño3.4 SST with a 100 year moving window for a 1,200 year period of the PCM pre-industrial (1870) control run (solid line) compared to the standard deviation of Niño3.4 SST from a 100 year segment in the PCM present-day control run (long dashed line), as well as the standard deviation of Niño3.4 for the 100 years of the stabilized $2 \times \mathrm{CO}_{2}$ (short dashed line) and $4 \times \mathrm{CO}_{2}$ (long-short dashed line) experiments. b Same as (a) except for a 510 year period of the CCSM3 pre-industrial (1870) control run (solid line) compared to the twentieth century stabilization experiment (long dashed line), the stabilized B1 experiment (short dashed line), and the stabilized A1B experiment (long-short dashed line).
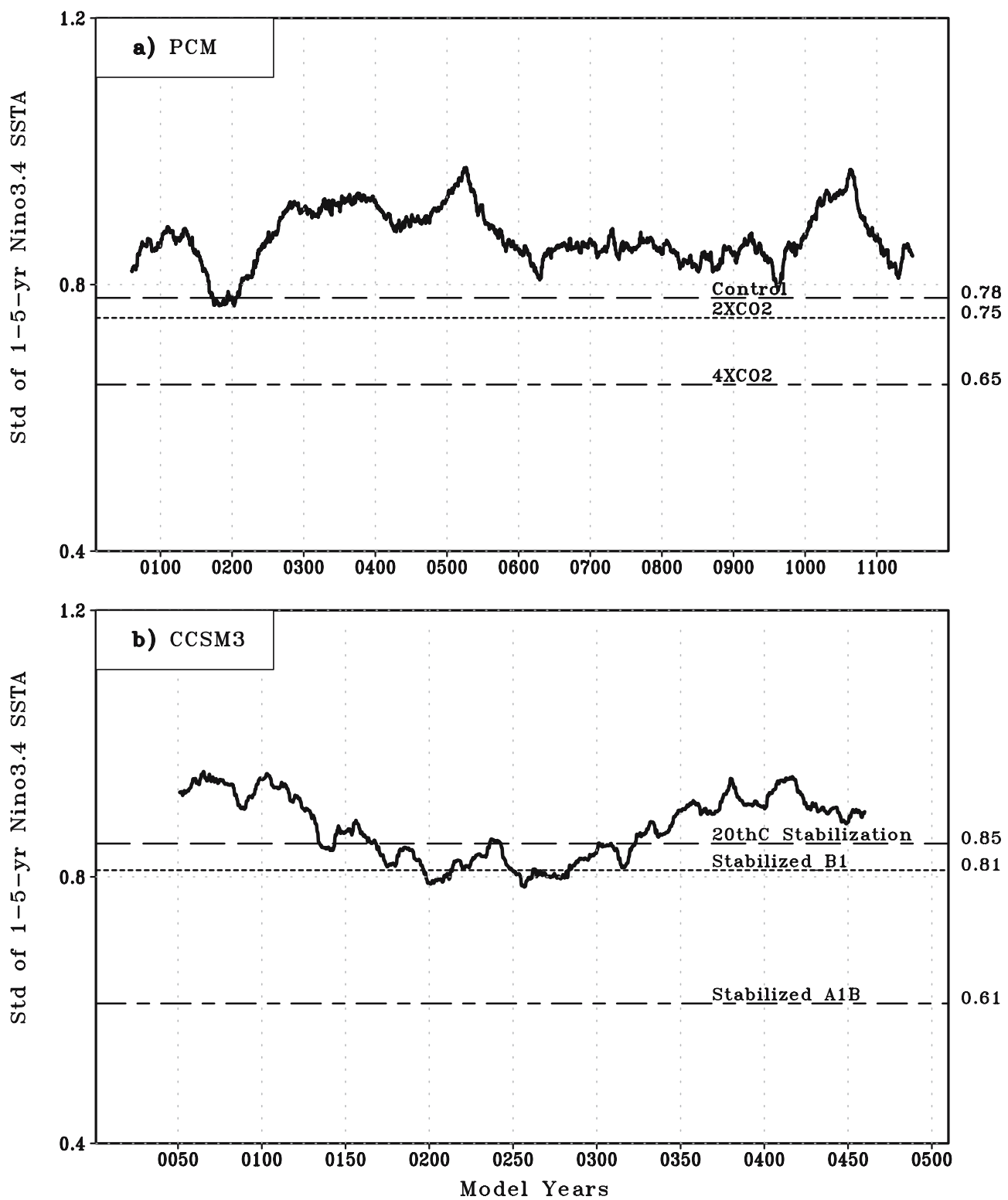

observations that show power spread over the roughly 2.5-7 year periods (Meehl et al. 2001; Deser et al. 2006). This feature is typical of some other current global coupled climate models (Latif et al. 2001; Achutarao and Sperber 2006). With greater positive radiative forcing in the $2 \times \mathrm{CO}_{2}$ and $4 \times \mathrm{CO}_{2}$ experiments in PCM, and $\mathrm{B} 1$ and $\mathrm{A} 1 \mathrm{~B}$ in CCSM3, there is a general decrease in power, with the biggest decreases for the greatest forcing in the $4 \times \mathrm{CO}_{2}$ experiment in PCM and the A1B experiments in CCSM3 (compared to the $2 \times \mathrm{CO}_{2}$ experiment in PCM and B1 experiment in CCSM3).

A significant issue noted earlier for any study of systematic changes in El Niño frequency or magnitude is the inherent low frequency variability of ENSO variance in the observations and models (e.g. Knutson and Manabe 1998). Therefore, to quantify low frequency variability in the control runs compared to the climate change experiments, Fig. 2a shows a time series of band pass filtered (1-5 years based on the dominant frequencies in Fig. 1) standard deviation of Niño3.4 SST with a 100 year moving window for a 1,200 year segment of the PCM pre-industrial control run, and a 500 year segment from the CCSM3 pre-industrial control run in Fig. 2b. As suggested in Fig. 1, compared to the 100 year present-day control run segment in PCM (standard deviation of $0.78^{\circ} \mathrm{C}$ ), and the 1,200 year preindustrial control run (standard deviation of $0.87^{\circ} \mathrm{C}$ ), Niño3.4 variability decreases with increasing positive radiative forcing, with somewhat smaller variability in the $2 \times \mathrm{CO}_{2}$ experiment (standard deviation of $0.75^{\circ} \mathrm{C}$ ) and even less variability in the $4 \times \mathrm{CO}_{2}$ experiment (standard deviation of $0.65^{\circ} \mathrm{C}$ ). Comparing the 100 year running window calculation of standard deviation of Niño3.4 SST from the 1,200 year segment of the preindustrial control run to the other experiments with PCM, Fig. 2a shows that the value for the 100 year 

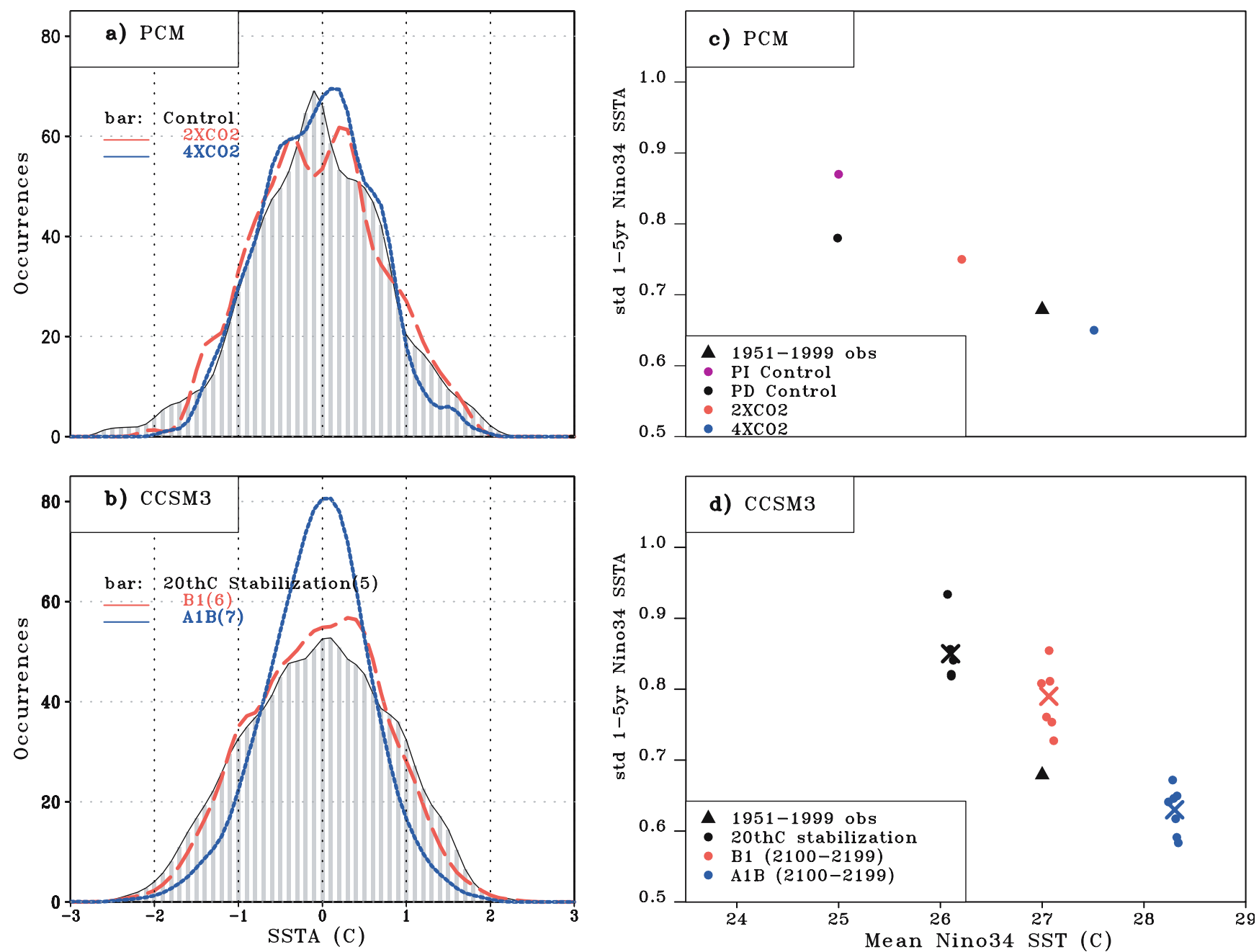

Fig. 3 a Histogram of band pass filtered (1-5 years) monthly Niño3.4 SST anomalies for the 100 year reference period in the PCM control run (bars), and the 100 years of the stabilized $2 \times \mathrm{CO}_{2}$ (long dashed line) and $4 \times \mathrm{CO}_{2}$ (short dashed line) experiments. b Same as (a) except for multi-member ensemble mean of twentieth century stabilization (bars), stabilized B1 experiment (long dashed line), and stabilized A1B experiment (short dashed line). c Standard deviations of Niño3.4 SST from the 1-5 year bandpass filtered SST data for PCM (dots) plotted as a function of mean Niño3.4 SST for

present-day control run is encompassed by the variability in the longer pre-industrial control run, and the value for $2 \times \mathrm{CO}_{2} 100$ year average lies just below the control runs. However, for the $4 \times \mathrm{CO}_{2}$ experiment, the lower value of Niño3.4 variability is well below any other 100 year period in the control experiments. Further analysis of these changes in variability will be performed in relation to Fig. 3 .

Similarly for CCSM3 (Fig. 2b), the reference variability in the stabilized twentieth century stabilization experiment is $0.85^{\circ} \mathrm{C}$, compared to the somewhat smaller value in the stabilized $\mathrm{B} 1$ experiment of $0.81^{\circ} \mathrm{C}$ which is still within the range of naturally occurring Niño3.4 variability in the control run. However, for the greater positive radiative forcing in the stabilized A1B experiment, the Niño3.4 variability drops to $0.61^{\circ} \mathrm{C}$ which is

pre-industrial control (purple dot), present-day control (black dot), stabilized $2 \times \mathrm{CO}_{2}$ (red dot), and stabilized $4 \times \mathrm{CO}_{2}$ (blue dot), black triangle is an observed estimate for 1950-1999 from Kaplan et al. (1997). d Same as (c) except for the CCSM3 twentieth century stabilization (black dots are the individual ensemble members, black $x$ is the concatenated time series), stabilized B1 (red dots are the individual ensemble members, $r e d \times$ is the concatenated time series) and A1B (blue dots are the individual ensemble members, blue $\times$ is the concatenated time series)

well outside the bounds of inherent variability in the model. Therefore, both models show a decrease of El Niño variability with increasing radiative forcing, but only with relatively large positive radiative forcing does this decrease fall well outside the limits of inherent low frequency El Niño variability.

Histograms of monthly Niño3.4 SST anomalies are shown in Fig. 3 for the present-day control run for $\mathrm{PCM}$ and the $2 \times \mathrm{CO}_{2}$ and $4 \times \mathrm{CO}_{2}$ experiments (Fig. 3a), and for the reference twentieth century stabilization run for CCSM3 and the stabilized B1 and A1B experiments (Fig. 3b). The amplitude change of El Niño events in the $\mathrm{B} 1$ and $\mathrm{A} 1 \mathrm{~B}$ experiments in PCM is negligible (not shown). The reduction in amplitude of El Niño events is seen for the $2 \times$ and $4 \times \mathrm{CO}_{2}$ El Niño events in PCM compared to the control run for this period in Fig. 3a 
as evidenced by smaller values at the far left and right parts of the histogram (fewer events of +2 or $-2^{\circ} \mathrm{C}$ magnitude). There are accordingly somewhat more low amplitude events (greater numbers of anomalies between about $\pm 1{ }^{\circ} \mathrm{C}$ ). Similarly, for the CCSM3 in Fig. 3b, there are decreases of the larger amplitude anomalies, but increases in the lower amplitude anomalies for both stabilized B1 and A1B compared to the twentieth century stabilization experiment. The curve for CCSM3 is smoother than for the PCM because the El Niño events are more regular across the different experiments in CCSM3 (Fig. 1), and the CCSM3 is taken from a multi-member mean. El Niño events do not cease in the models, but the events that do occur are of smaller amplitude with increasing radiative forcing.

Another depiction of the relative change of El Niño amplitude is shown in Fig. 3c and d. The 100 year standard deviations of Niño3.4 SST for pre-industrial PCM control, the present-day PCM control, stabilized $2 \times \mathrm{CO}_{2}$ and stabilized $4 \times \mathrm{CO}_{2}$ (Fig. 3c) and for CCSM3 the twentieth century stabilization, and stabilized $\mathrm{B} 1$ and A1B experiments (Fig. 3d) are plotted as a function of the mean Niño3.4 SST. An estimate from observations is plotted for comparison, computed for the period 19501999 from the Kaplan et al. (1997) SST data. Even during this time period of the observations there was low frequency variability of El Niño variance, and computing this value for different subperiods would also produce different amplitudes. For example, the pre- and post-1976 regimes showed different El Niño behavior, with the former characterized by more SST-mode events which would compare better with CCSM3 and PCM than the latter period (Guilyardi 2005). However, the change in the mid-1970s could have been either natural, forced, or some combination so it is unclear how that regime-change can be related to the type of El Niño events simulated in these models.

PCM has a colder Niño 3.4 base state (about $1{ }^{\circ} \mathrm{C}$ ) compared to CCSM3. In Fig. 2, the Niño 3.4 standard deviation for the 100 year segment of the PCM presentday control run is $0.78^{\circ} \mathrm{C}$, for the 1,200 year segment of the PCM preindustrial control run it is $0.87^{\circ} \mathrm{C}$, and for CCSM3 in the stabilized twentieth century experiment that value is $0.85^{\circ} \mathrm{C}$. An $f$ test shows these differences are statistically insignificant at the $10 \%$ level. The different levels of El Niño variability are likely related to the different slopes of the themocline in the control runs in the models (Fig. 4), where the present-day PCM control run has a somewhat deeper thermocline in the eastern equatorial Pacific (Fig. 4a) compared to the CCSM3 stabilized twentieth century simulation (Fig. 4e). These features have been shown to affect El Niño amplitude in this class of model (Meehl et al. 2001). As will be discussed below, such changes in the thermocline can also produce differences in El Niño amplitude in these models for different forcings.

For the PCM (dots in Fig. 3c), the lower El Niño amplitude in the $2 \times \mathrm{CO}_{2}$ experiment is not significant at the $10 \%$ level from an $f$ test compared to the preindustrial control. However, the decrease in El Niño amplitude in the $4 \times \mathrm{CO}_{2}$ experiment is statistically significant at the $10 \%$ level compared to the pre-industrial control. There is also a decrease of El Niño amplitude in PCM going from a lower forcing experiment (stabilized B1) to a higher forcing experiment (stabilized A1B) (not shown). But this decrease (from an ensemble mean stabilized $\mathrm{B} 1$ experiment of $0.79^{\circ} \mathrm{C}$, to the stabilized $\mathrm{A} 1 \mathrm{~B}$ experiment ensemble mean of $0.74^{\circ} \mathrm{C}$ ) is not statistically significant.

For CCSM3 in Fig. 3d, this reduction in El Niño amplitude is greater, going from a standard deviation of the concatenated time series in stabilized $\mathrm{B} 1$ of $0.79^{\circ} \mathrm{C}$ (the $\times$ in Fig. 3d; the dots represent the individual ensemble members) to $0.63^{\circ} \mathrm{C}$ in stabilized A1B. Results from an $f$ test show that the reduced amplitude in the stabilized A1B experiment is significant at the $10 \%$ level, but the reduced amplitude in stabilized B1 compared to the twentieth century stabilization experiment is not significant.

However, these are El Niño responses in stabilized forcing experiments. There is the question if such changes could be seen in transient twenty-first century experiments. Similar calculations to those in Fig. 3d are made for PCM and CCSM3 for the 100 year time period from 2000 to 2100 in the transient climate change experiments for B1, A1B and A2 (a high forcing scenario, for example, $\mathrm{CO}_{2}$ increases to $820 \mathrm{ppm}$ or $226 \%$ of the year 2000 value, $2.26 \times \mathrm{CO}_{2}$ ), compared to the twentieth century stabilization experiment (not shown). By band-pass filtering the time series (1-5 years), we essentially detrend the data, and the standard deviations of Niño3.4 can then be compared in these transient experiments. Ensemble mean Niño3.4 standard deviation shows little reaction to the GHG forcing in PCM, with the ensemble mean value from the reference twentieth century stabilization experiment of $0.75^{\circ} \mathrm{C}$, while for the transient experiments it is $0.76^{\circ} \mathrm{C}$ in $\mathrm{B} 1,0.75^{\circ} \mathrm{C}$ in $\mathrm{A} 1 \mathrm{~B}$, and $0.75^{\circ} \mathrm{C}$ in $\mathrm{A} 2$. However, the larger response to increased radiative forcing seen for the CCSM3 in Fig. 3c is also evident in the transient twenty-first century CCSM3 experiments, with the ensemble mean Niño3.4 SST standard deviation value for the twentieth century stabilization experiment of $0.85^{\circ} \mathrm{C}, 0.83^{\circ} \mathrm{C}$ in $\mathrm{B} 1,0.76^{\circ} \mathrm{C}$ in $\mathrm{A} 1 \mathrm{~B}$, and $0.76^{\circ} \mathrm{C}$ in $\mathrm{A} 2$. None of these decreases are significant at the $10 \%$ level from an $f$ test.

Therefore, depending on the model and the size of the positive radiative forcing, the decrease in El Niño amplitude seen across both models for all experiments only exceeds either inherent low frequency El Niño variability or is significant at the $10 \%$ level from an $f$ test for the relatively large forcing in the $4 \times \mathrm{CO}_{2}$ experiment in PCM, and the stabilized A1B experiment in CCSM3. The others show indications of reduction of El Niño amplitude with increased positive radiative forcing, but none are statistically significant for either stabilized or transient experiments. 
a) PCM control

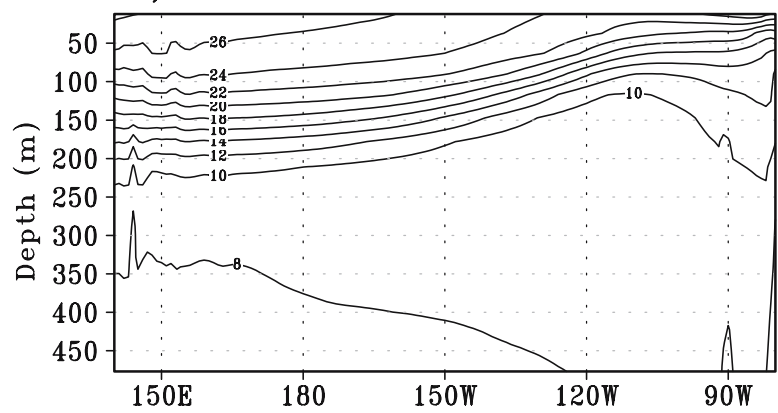

c) $\mathrm{PCM} 2 \mathrm{XCO} 2$

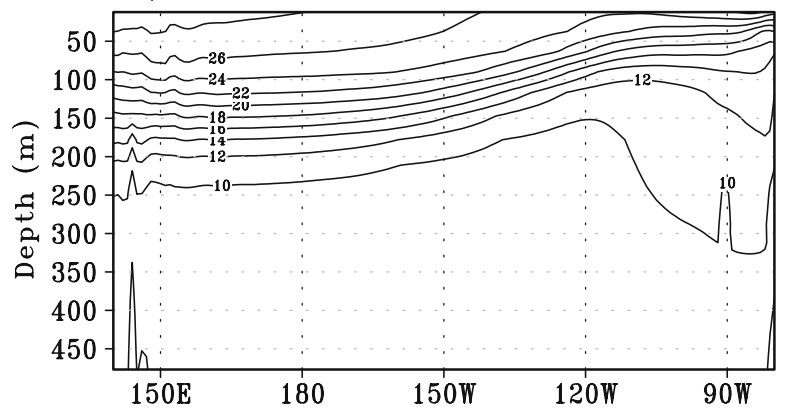

e) CCSM3 20thC stabilization

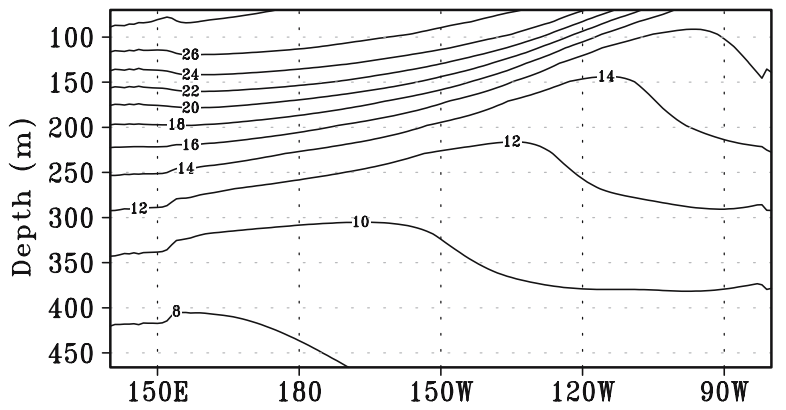

g) CCSM3 stabilized B1

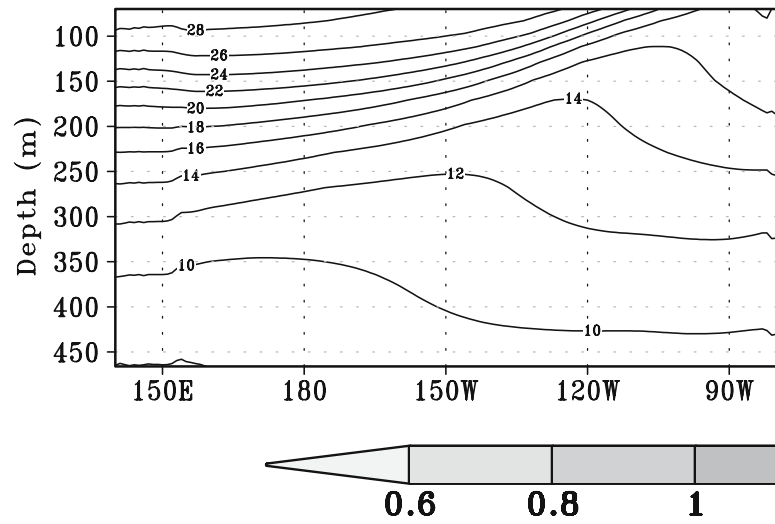

Fig. 4 a A 100 year mean ocean temperatures along section of the equatorial Pacific for the PCM control experiment. b Temperature differences (100 year average) for PCM $2 \times \mathrm{CO}_{2}$ minus control. c Same as (a) except for PCM $2 \times \mathrm{CO}_{2}$. d Same as (b) except for PCM $4 \times \mathrm{CO}_{2}$. e Same as (a) except for CCSM3 twentieth century stabilization experiment. f Same as (b) except for CCSM3 stabilized B1 minus twentieth century stabilization experiment. g Same as (a) except for CCSM3 stabilized B1. h Same as (b) except for CCSM3 b) $\mathrm{PCM} 2 \mathrm{XCO} 2$ minus control

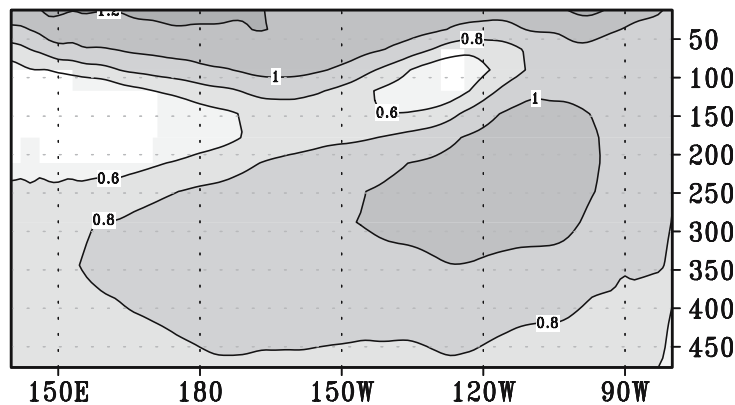

d) $\mathrm{PCM} 4 \mathrm{XCO} 2$ minus control

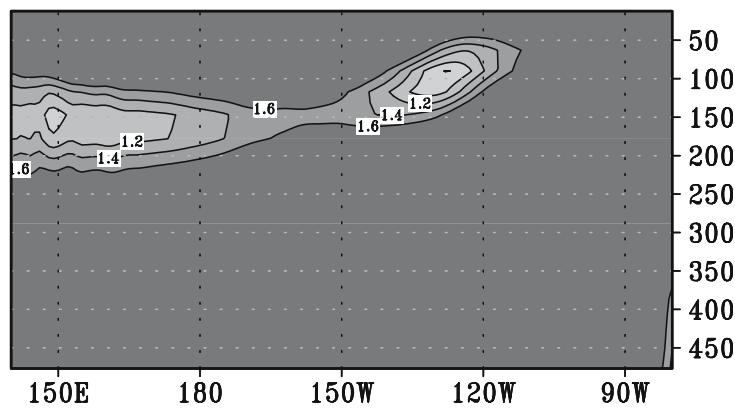

f) CCSM3 B1 minus 20thC stabilization

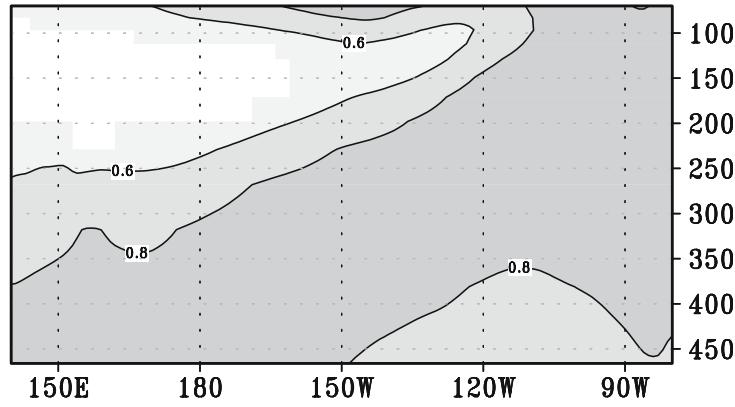

h) CCSM3 A1B minus 20thC stabilization
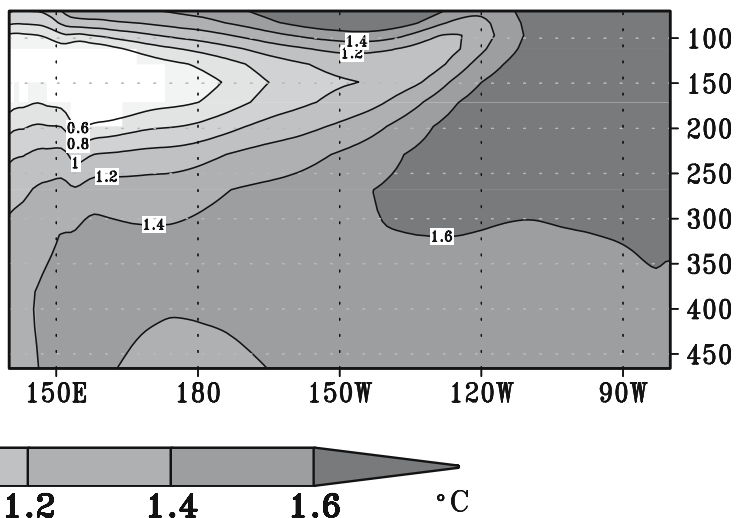

stabilized A1B minus twentieth century stabilization experiment. i PCM zonal mean ocean temperatures $\left({ }^{\circ} \mathrm{C}\right.$, colored contours), and meridional overturning streamfunction $\left(\mathrm{Sv}, 106 \mathrm{~m}^{3} \mathrm{~s}^{-1}\right.$, black contours) for the upper $400 \mathrm{~m}$, Pacific basin, present-day control run, 50 year average. $\mathbf{j}$ Same as (i) except CCSM3 twentieth century stabilization experiment (2050-2099). k PCM $2 \times$ CO2 (years 19611980) minus control experiment in (i). I Stabilized A1B (2150-2199) minus twentieth century stabilization experiment $(2050-2099)$ in (j) 


\section{Pacific STC, zonal mean T and their anomalies (left: PCM; right: CCSM)}
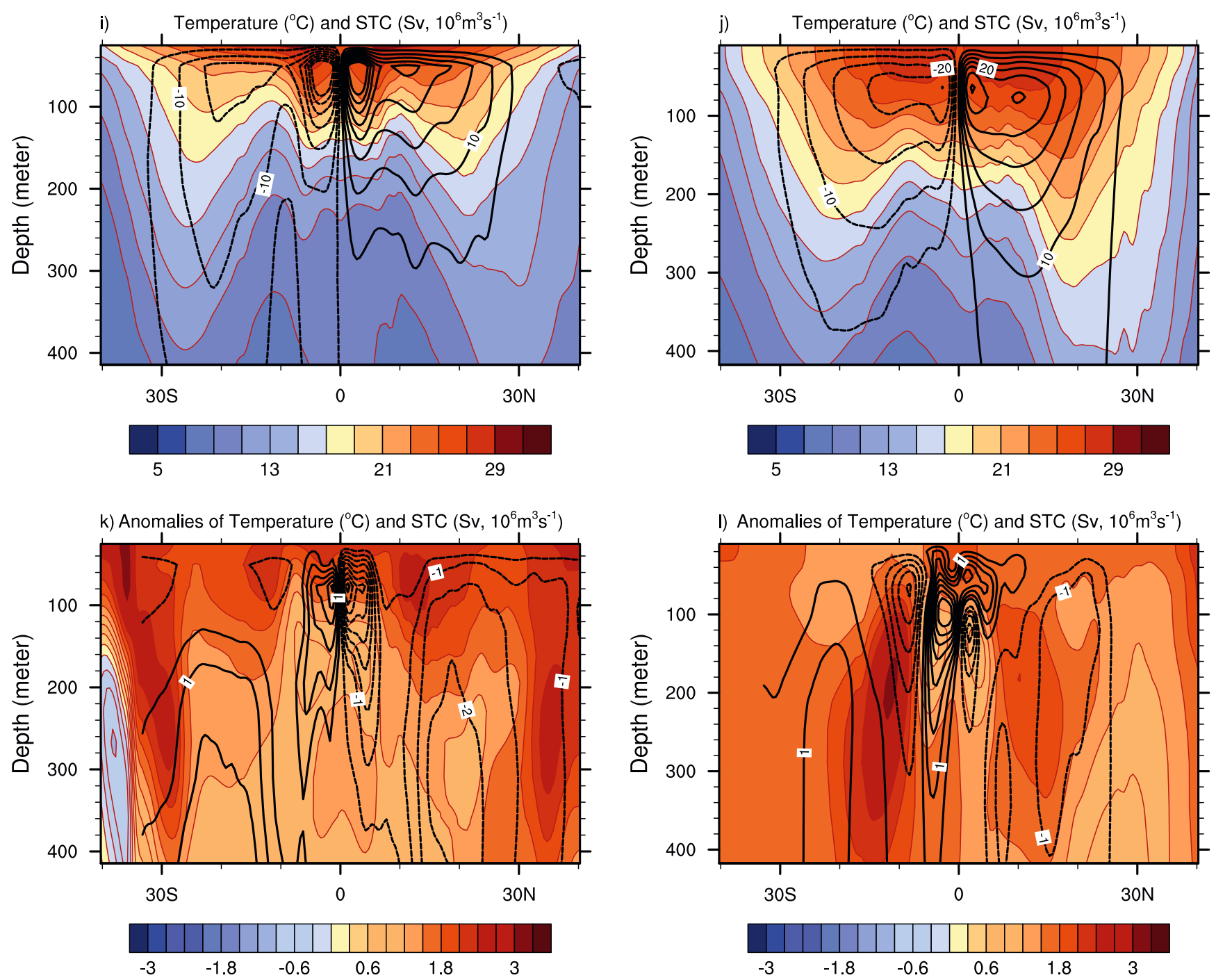

Fig. 4 (Contd.)

\section{Reasons for the changes in El Niño in the models}

Meehl et al. (2001) identified the importance of upper ocean temperature structure for amplitude of El Niño events in PCM in a series of sensitivity experiments changing the ocean background vertical diffusivity. The PCM is characterized mostly by SST-mode events, though some thermocline mode events occur in the model. They showed that the warmer and more diffuse the thermocline in that model, the lower the El Niño amplitude. The relevance of these features was shown for the case of decadal variability in the Pacific by Arblaster et al. (2002). They showed that a deeper, warmer thermocline in the PCM produced lower amplitude El Niño events during warm periods in the tropical Pacific on the multi-decadal timescale, while a cooler more shallow thermocline produced higher amplitude El Niño events on that timescale. This result was consistent with the earlier Meehl et al. (2001) sensitivity experiments and with observations shown in that study.

To examine aspects of the upper ocean temperature structure along the equator in the Pacific for the present two models, Fig. 4 shows the 100 year mean temperatures for control and $2 \times \mathrm{CO}_{2}$ (Fig. 4a, c) as well as the differences of $2 \times \mathrm{CO}_{2}$ and $4 \times \mathrm{CO}_{2}$ minus control (Fig. $4 \mathrm{~b}$, d) for PCM. For CCSM3, similar plots are shown for the mean equatorial temperatures for the twentieth century stabilization and stabilized B1 experiments (Fig. 4e, g), and for the stabilized B1 minus twentieth century stabilization (Fig. 4f) and stabilized A1B minus twentieth century stabilization (Fig. 4h). For all the PCM and CCSM3 experiments, there is a well-resolved thermocline, with a mean depth of around $150 \mathrm{~m}$ in the west, sloping upwards toward the east to a depth of about $50 \mathrm{~m}$ similar to observations (e.g. see Meehl et al. 
a) PCM Control
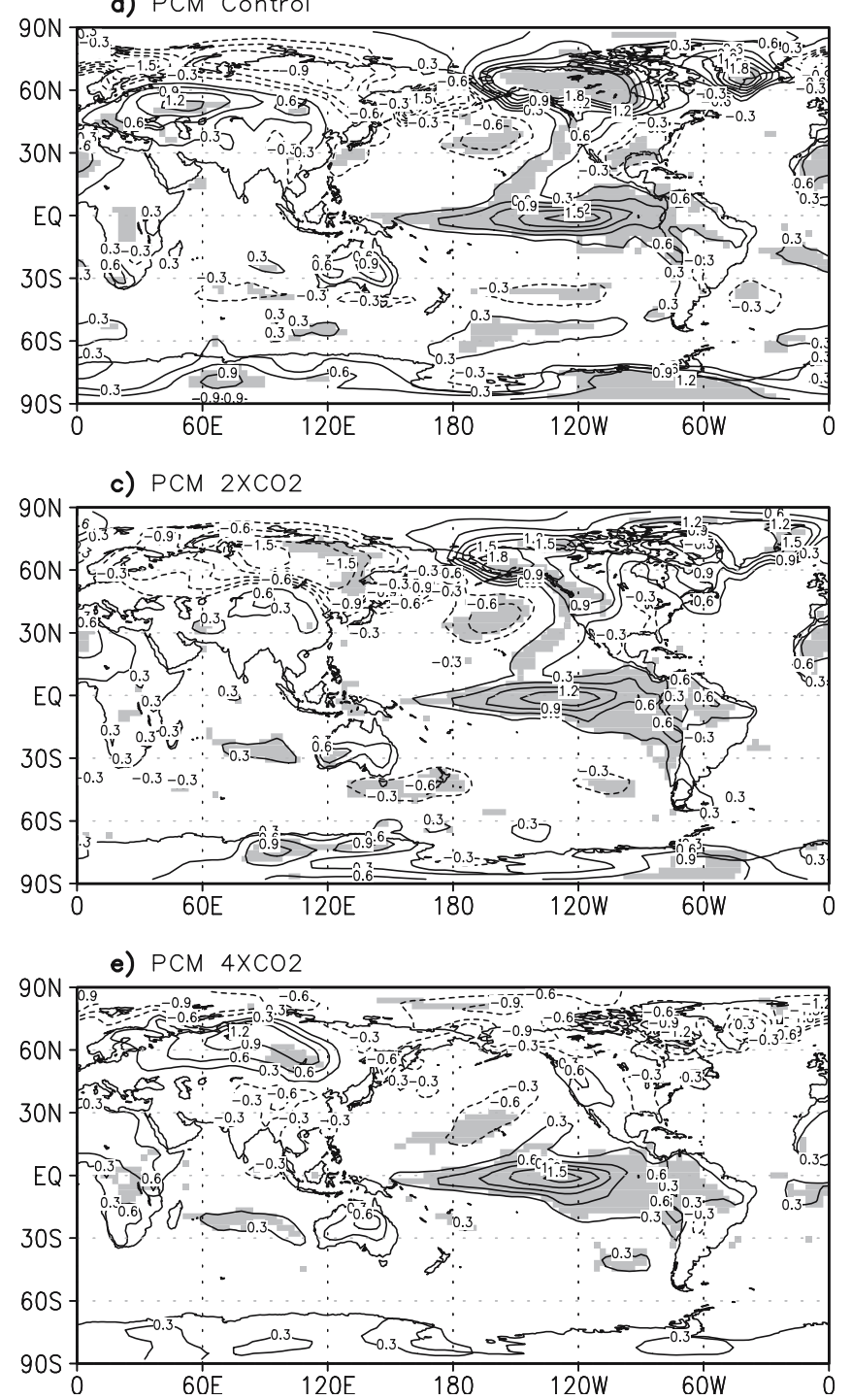

Fig. 5 Composite DJF surface temperature anomalies $\left({ }^{\circ} \mathrm{C}\right)$ for $\mathrm{El}$ Niño events in (a) the PCM control run, (b) CCSM3 twentieth century stabilization, (c) PCM $2 \times \mathrm{CO} 2$, (d) CCSM3 stabilized B1, (e) $\mathrm{PCM} 4 \times \mathrm{CO} 2$, and (f) $\mathrm{CCSM} 3$ stabilized A1B. Anomalies are

2001). The temperature changes at the right part of the figure show warming at all levels for both models, but with greater warming near the surface and beneath the thermocline and lower amplitude warming in the thermocline.

The warming above the thermocline can be understood as heating from the surface, but the warming below the thermocline is more intriguing and can be traced in part to a reduction of the east-west equatorial SST gradient, a consequent weakening of the trade winds, and a reduction of upwelling. It is also related in part to changes in the subtropical cells (STCs) in the Pacific. The mean STCs and associated mean zonally averaged temperatures are shown in Fig. 4i and $\mathrm{j}$ for the PCM and CCSM3, respectively. The downward extent of the isotherms near $20^{\circ} \mathrm{N}$ and $20^{\circ} \mathrm{S}$ is associated with convergence and subsidence in the STCs, while the upward b) $\operatorname{ccs} 3320$ thC stabilization

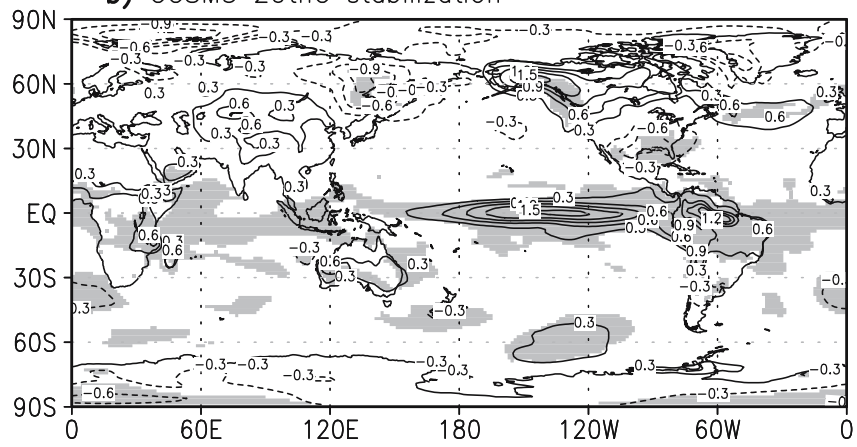

d) $\operatorname{Ccsm} 3$ stabilized $B 1$
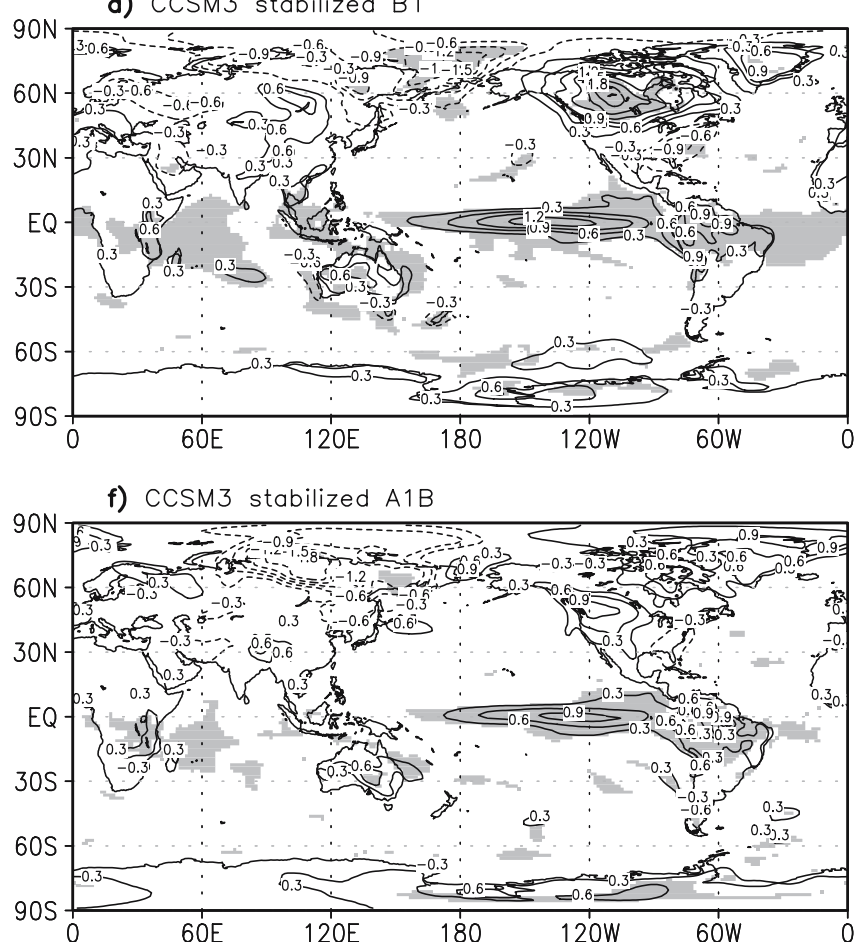

calculated relative to the respective 100 year mean temperature in the experiments. Contours denote differences, and shaded areas are significant at the $10 \%$ significance level

reach of the sub-thermocline isotherms is associated with upward transport in the STCs. Maximum mean values of meridional streamfunction characterizing STC strength are greater than $20 \mathrm{~Sv}$ in both models.

Previous studies have indicated that a reduction of the trade winds in the tropical Pacific can produce a weakening of the STCs, which in turn lead to a deeper and more diffuse thermocline in observations (McPhaden and Zhang 2002) and in models (Kleeman et al. 1999; Nonaka et al. 2001; Solomon et al. 2003).

As noted above, with increasing GHG forcing, there is a warming of the equatorial Pacific SSTs, a reduction of the east-west SST gradient, and a weakening of the trade winds in both models, particularly in the western Pacific (not shown). Consequently, the wind-driven STCs also weaken by roughly $5 \mathrm{~Sv}$ (about $25 \%$ ), as shown in Fig. $4 \mathrm{k}$ and 1 for the two models 


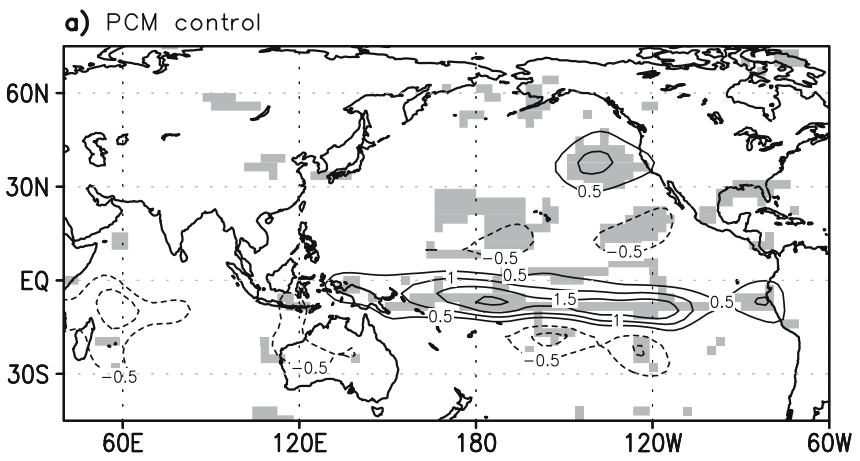

c) $\mathrm{PCM} 2 \times \mathrm{CO} 2$ anoms minus $\mathrm{Ctrl}$ anoms

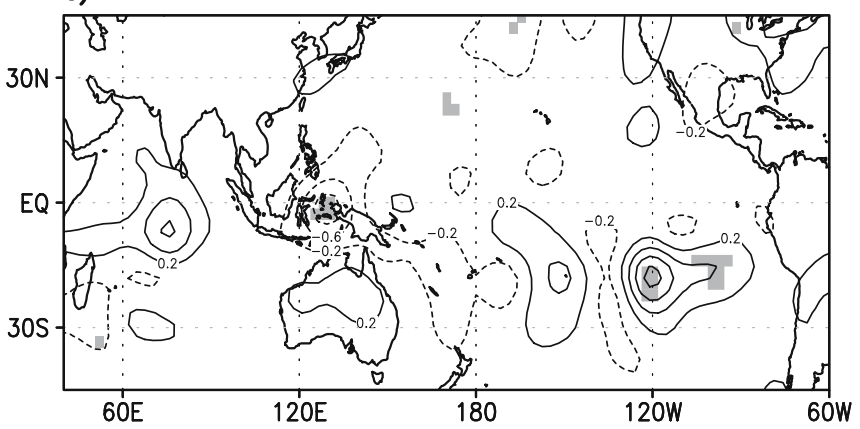

e) $\mathrm{PCM} 4 \mathrm{XCO} 2$ anoms minus $\mathrm{Ctrl}$ anoms

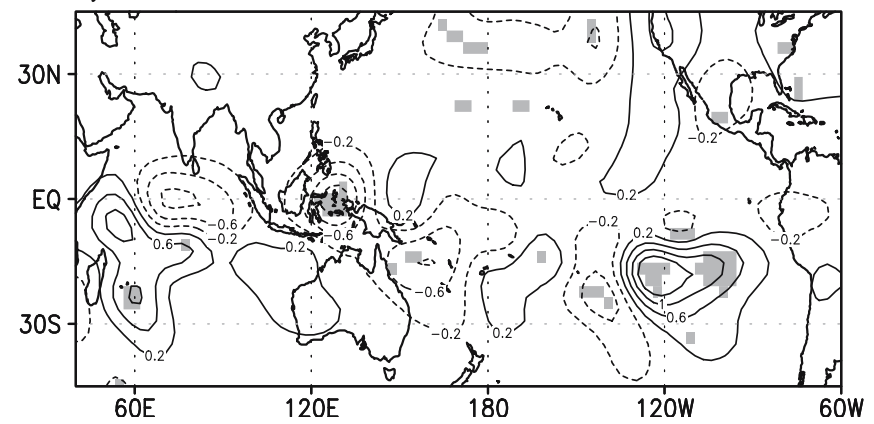

Fig. 6 a Composite DJF El Niño precipitation anomalies spatially smoothed from the PCM control run $\left(\mathrm{mm} \mathrm{day}^{-1}\right)$. b Same as (a) except for the CCSM3 twentieth century stabilization experiment. c Composite precipitation anomaly differences for PCM $2 \times \mathrm{CO} 2 \mathrm{El}$ Niño event precipitation anomalies minus PCM control run El Niño event precipitation anomalies $\left(\mathrm{mm} \mathrm{day}^{-1}\right)$. d Same as (b)

(as indicated by the opposite sign anomalies of this magnitude compared to the sign of the mean meridional streamfunction in Fig. 4i and j). These weakened STCs therefore contribute to a weaker and more diffuse thermocline as indicated by zonal mean temperature anomalies greater than $+1{ }^{\circ} \mathrm{C}$ near a depth of $250 \mathrm{~m}$ at the equator. Evidence of this more diffuse thermocline can be given by the thermocline intensity index defined by Meehl et al. (2001) as the depth between the 16 and $22^{\circ} \mathrm{C}$ isotherms at equator, $155^{\circ} \mathrm{W}$. In the CCSM3, for example, this index is $40 \mathrm{~m}$ in the twentieth century stabilization experiment, $50 \mathrm{~m}$ in the stabilized B1 experiment, and $60 \mathrm{~m}$ in the stabilized A1B experiment. Therefore, following the conclusions of Meehl et al. (2001) and Arblaster et al. (2002), the warmer and more diffuse thermocline results in lower

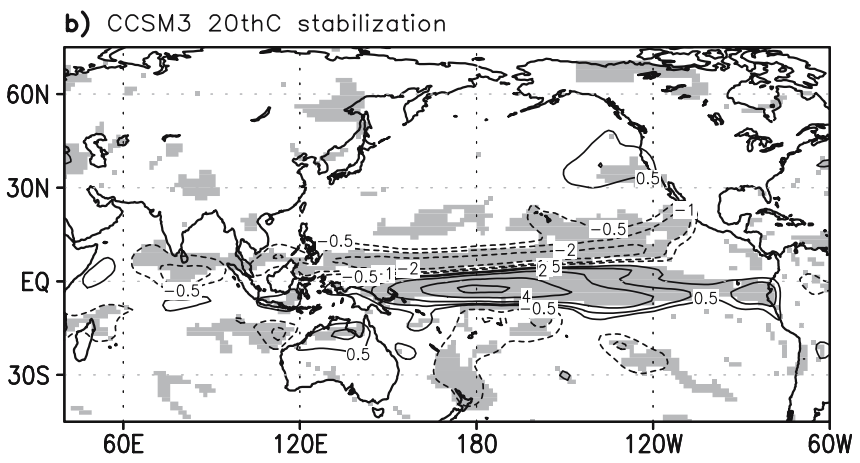

d) CCSM3 B1 anoms minus 20thC stabilization anoms

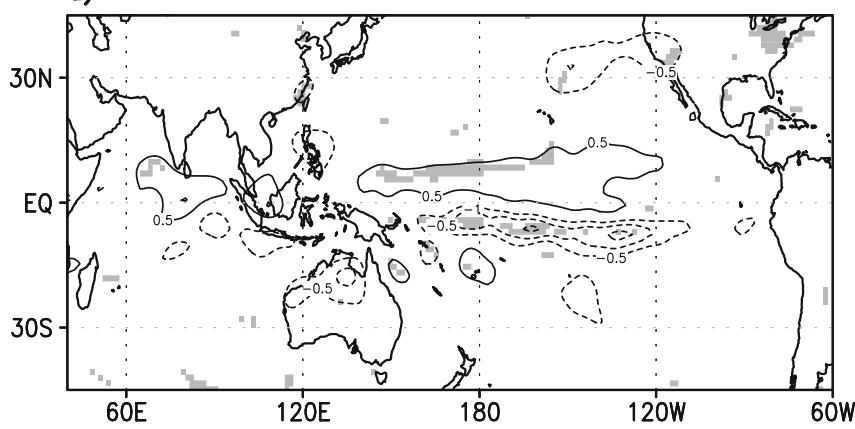

f) $\operatorname{Ccs} 33 \mathrm{~A} 1 \mathrm{~B}$ anoms minus 20 thC stabilization anoms

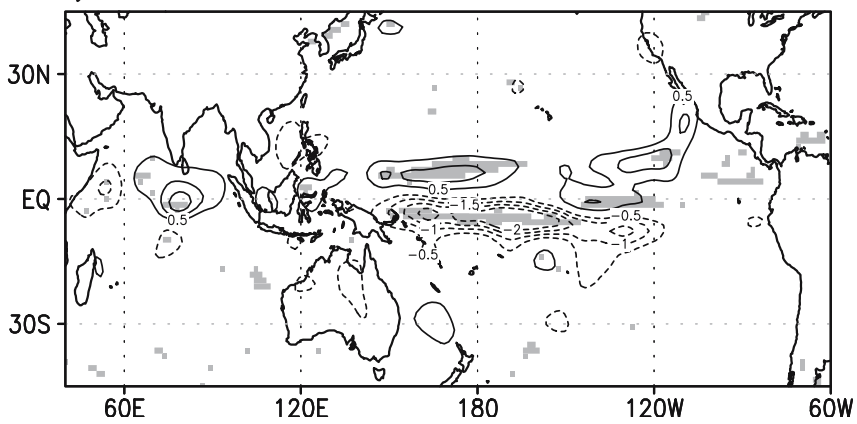

except for CCSM3 stabilized B1 El Niño event precipitation anomalies minus CCSM3 twentieth century stabilization experiment El Niño event precipitation anomalies. e Same as (c) except for PCM $4 \times \mathrm{CO} 2$. f Same as (d) except for CCSM3 A1B. Contour are anomalies, and shading represents the $10 \%$ significance level

amplitude El Niño events with increased GHGs in these models.

\section{Changes in El Niño teleconnections to northern mid- latitudes}

To examine the nature of the changes in variability, we define an El Niño event as a Niño3.4 anomaly (time series band pass filtered at 1-5 years) that exceeds one standard deviation for the December-January-February season when El Niño amplitude is greatest and thus the teleconnections to the Northern Hemisphere are largest (e.g. Meehl 1987; Yasunari 1991). The year of the El Niño (year 0) is then the first calendar year the El Niño occurs (e.g. van Loon et al. 2003). For the 100 year 
a) PCM control

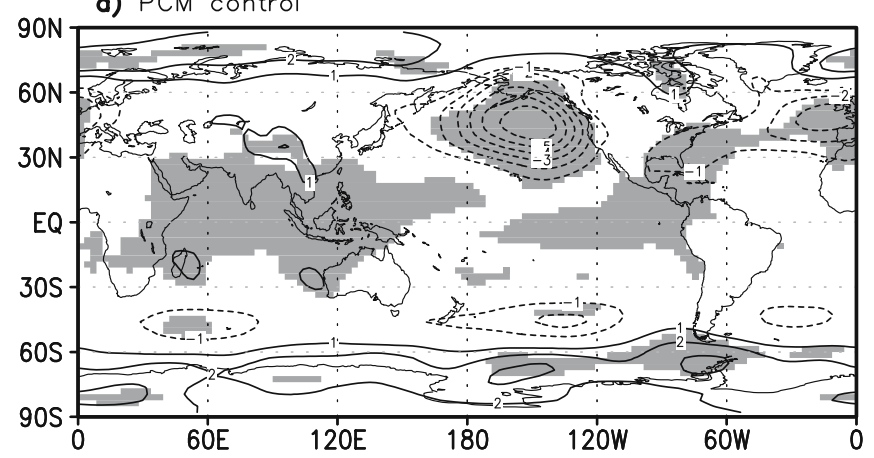

c) $\mathrm{PCM} 2 \times \mathrm{CO} 2$

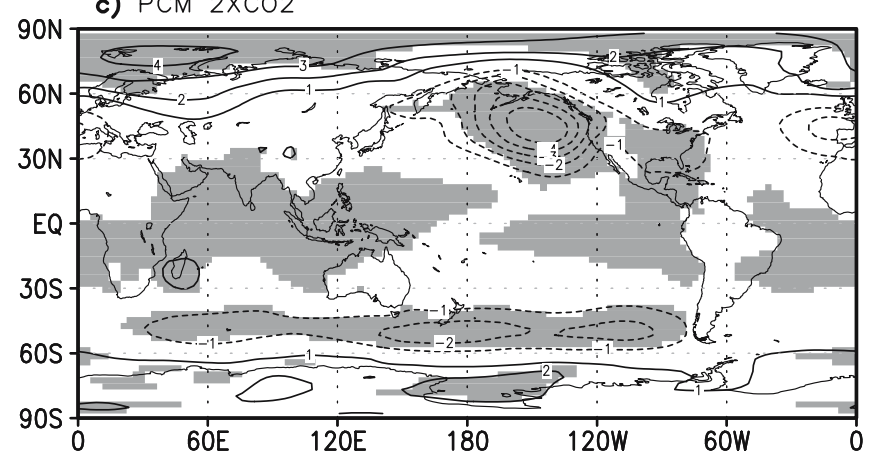

e) $\mathrm{PCM} 4 \times \mathrm{XCO} 2$

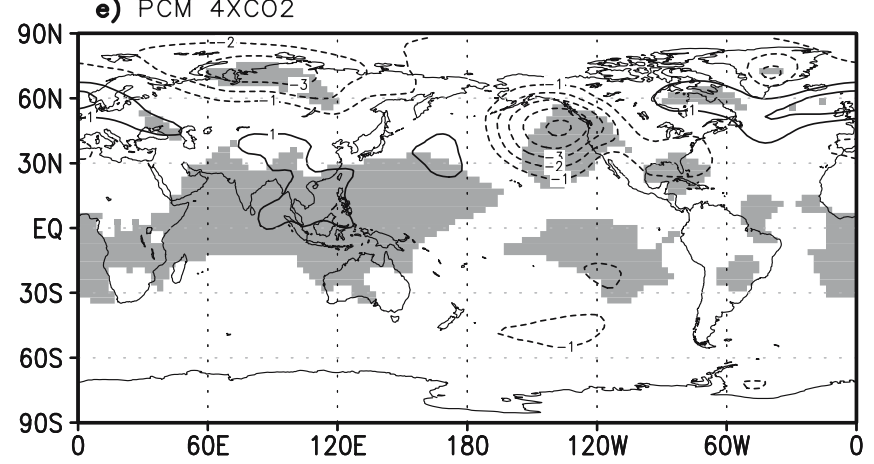

Fig. 7 Composite DJF sea level pressure anomalies (hPa) for (a) El Niño events in the PCM control run; (b) El Niño events in the CCSM3 twentieth century stabilization experiment; (c) same as (a) except for PCM $2 \times \mathrm{CO} 2$ experiment; (d) same as (b) except for

reference period in the PCM control run, there are 14 such events, 16 in the 100 years of the stabilized $2 \times \mathrm{CO}_{2}$ experiment, and 14 in the 100 years of stabilized $4 \times \mathrm{CO}_{2}$ experiment. For CCSM3, there are 19 in the 100 years of the twentieth century stabilization experiment, and 15 in stabilized B1, and 11 in stabilized A1B.

Composite surface temperature anomalies for El Niño events during DJF in the control run, and stabilized $2 \times \mathrm{CO}_{2}$ and $4 \times \mathrm{CO}_{2}$ experiments from PCM are shown in Fig. 5a, c and e, and for twentieth century stabilization, stabilized $\mathrm{B} 1$ and $\mathrm{A} 1 \mathrm{~B}$ for CCSM3 in Fig. 5b, d, and f. Anomalies are contoured, and shaded areas denote differences significant at the $10 \%$ level according to a $t$ test. The larger decreases in El Niño amplitude with increased radiative forcing in CCSM3 are evident in the equatorial Pacific comparing Fig. 5b, b) $\operatorname{ccs} 320$ the stabilization

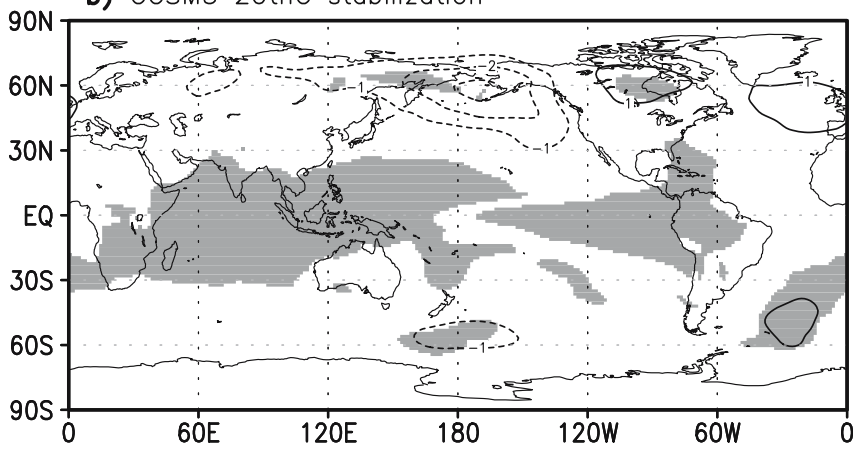

d) $\operatorname{CCSM} 3$ stabilized B1
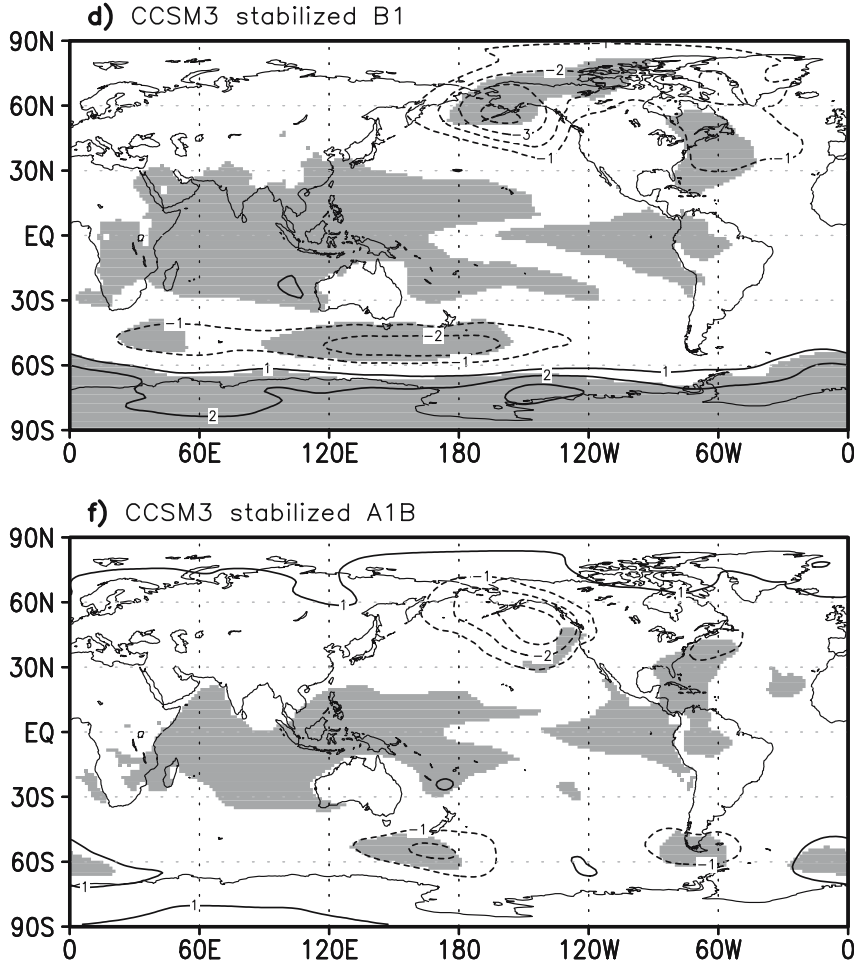

CCSM3 stabilized B1 experiment; (e) same as (c) except for PCM $4 \times \mathrm{CO} 2$ experiment; (f) same as (d) except for CCSM3 stabilized A1B experiment. Contours are anomalies, and shading represents the $10 \%$ significance level

$\mathrm{d}$, and $\mathrm{f}$ to PCM in Fig. 5a, c and e (as could be expected from Figs. 1 and 2). In fact, the interannual standard deviations in the eastern equatorial Pacific in PCM (Fig. 5a, c and e) show little change in this depiction, though it is evident from Fig. 2 that Niño3.4 variability decreases with large radiative forcing.

Temperature anomalies in the baseline El Niño events (control run for PCM in Fig. 5a, and twentieth century stabilization for CCSM3 in Fig. 5b) show cooling over eastern Siberia, significant warming over Alaska, northern Canada, and parts of northwestern North America, and significant cooling over the southern tier of the United States. This is similar to canonical temperature differences for observed El Niño events (e.g. Ropelewski and Halpert 1987). However, with increasing radiative forcing in the models, these midlatitude 
a) PCM SLP Strong (42cases, hPa)

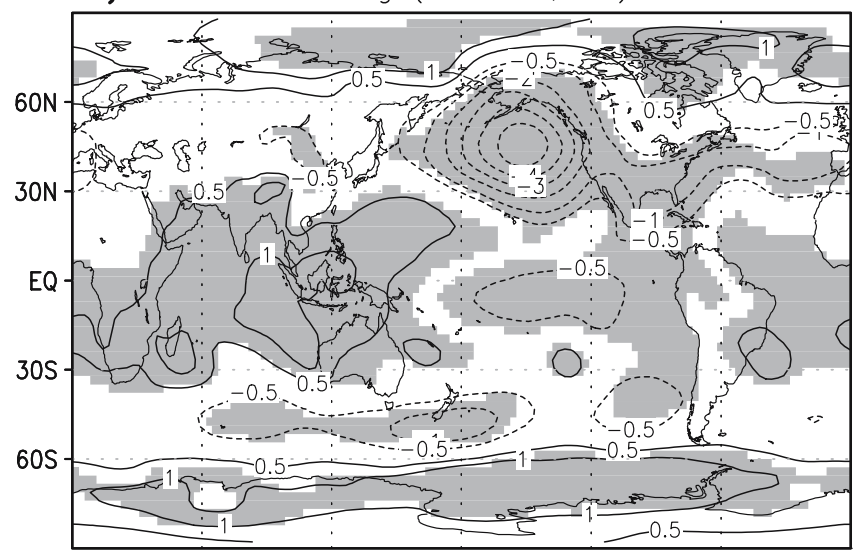

c) PCM SLP Moderate (49cases, hPa)

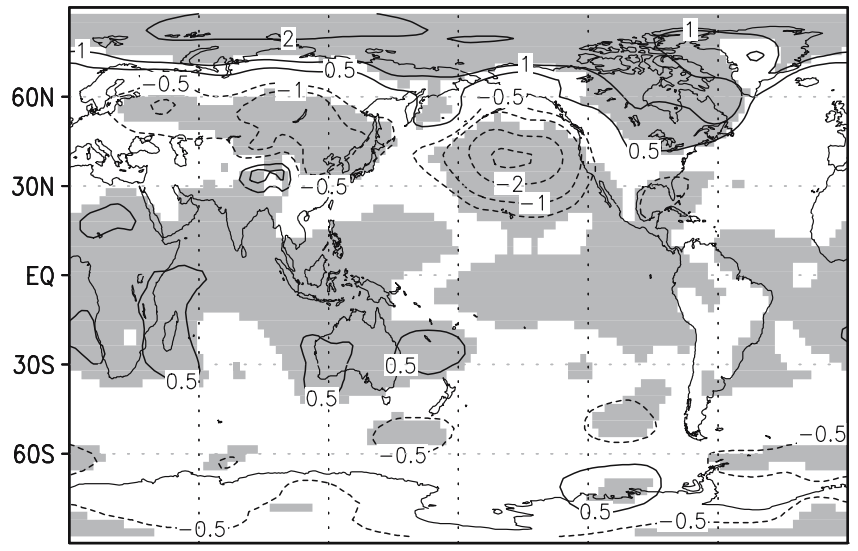

b) CCSM3 SLP Strong (39cases, $\mathrm{hPa}$ )

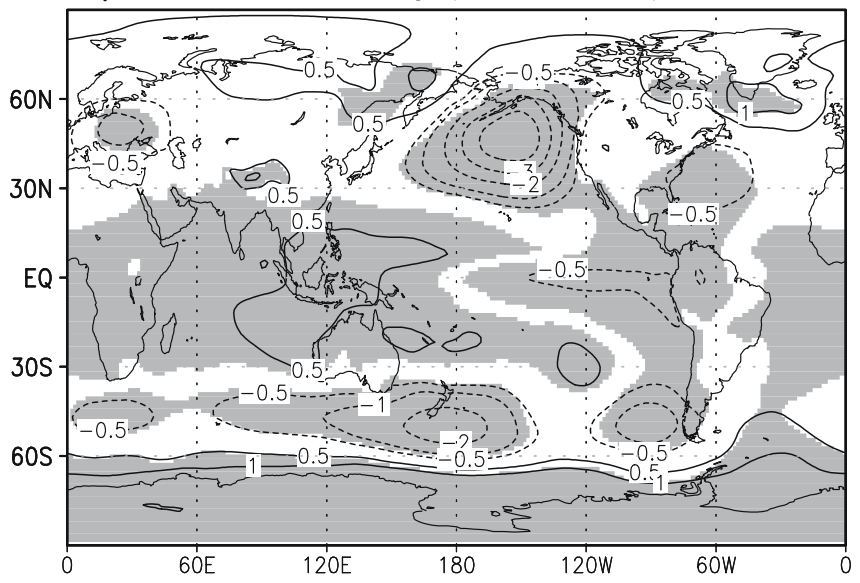

d) CCSM3 SLP Moderate (41cases, hPa)

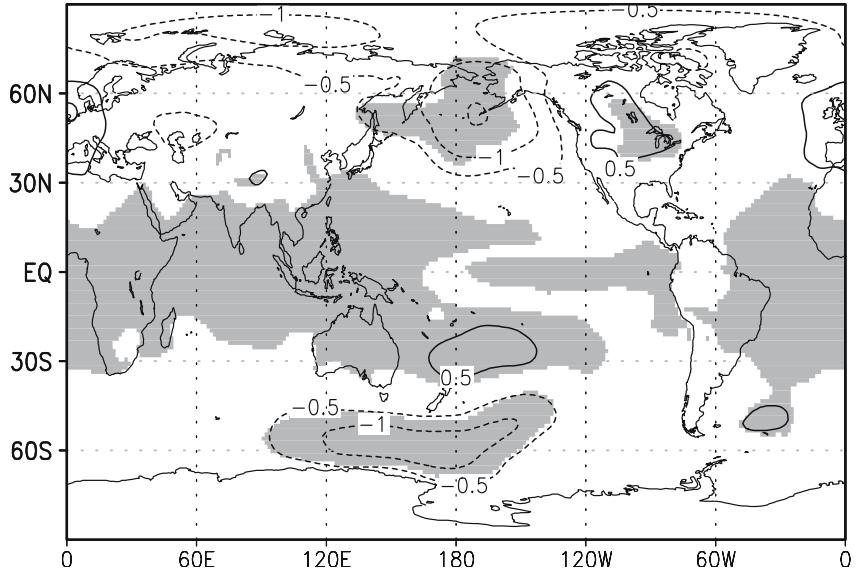

Fig. 8 a Composite DJF SLP anomalies (hPa) from PCM for strong El Niño events as defined in the text. b Same as (a) except for CCSM3. c Same as (a) except for moderate El Niño events. d Same as (c) except for CCSM3

temperature anomalies weaken. In particular over North America for the largest forcing $\left(4 \times \mathrm{CO}_{2}\right.$ in PCM and stabilized A1B in CCSM3), there are no longer any significant temperature anomalies over North America during El Niño events (Fig. 5e, f).

To examine the tropical precipitation anomalies for the baseline El Niño events in the models, Fig. 6a and b shows precipitation anomalies for DJF (all anomalies in Fig. 6 have been spatially smoothed). There are positive values over the anomalously warm water in the equatorial Pacific for both models, and negative anomalies over areas of Australasia as observed during El Niño events (e.g. Meehl 1987). For El Niño events in a warmer mean climate, there is no clear intensification of precipitation anomalies compared to present-day events due to the smaller amplitude El Niño SST anomalies (Figs. 1, 2, 4). Additionally, there are smaller amplitude precipitation anomalies in lower amplitude El Niño events (not shown, and discussed further in the next section). It has been noted in previous studies (e.g. Meehl et al. 1993; Cubasch et al. 2001) that enhanced El Niño precipitation anomalies in future events could occur because the base state SSTs increase nearly everywhere in the tropics with increasing $\mathrm{CO}_{2}$. The idea was that due to the nonlinear effects of evaporation with increasing SST, El Niño events in the future climate would produce more intense precipitation anomalies in the presence of those warmer SSTs, though such results had some elements of model-dependence (Cubasch et al. 2001). However, in Fig. 6c-f, which show the difference between El Niño precipitation under enhanced $\mathrm{CO}_{2}$ conditions and under baseline conditions, there is some indication of more anomalously dry conditions over Australasia in the PCM $2 \times \mathrm{CO}_{2}$ and $4 \times \mathrm{CO}_{2}$ simulations (Fig. 6c, e), though these are only marginally statistically significant. For the CCSM3 stabilized B1 and A1B experiments (Fig. 6d, f), there are actually decreases of precipitation anomalies in the equatorial Pacific, consistent with the decreased amplitude of El Niño events in this model (e.g. Fig. 3d), and little consistent change of El Niño precipitation anomalies over Australasia. Therefore, the previously noted intensification of $\mathrm{El}$ Niño precipitation anomalies in a warmer mean base state that applied when there was no appreciable change 
a) $\mathrm{PCM} 2 \times \mathrm{CO} 2$ minus control

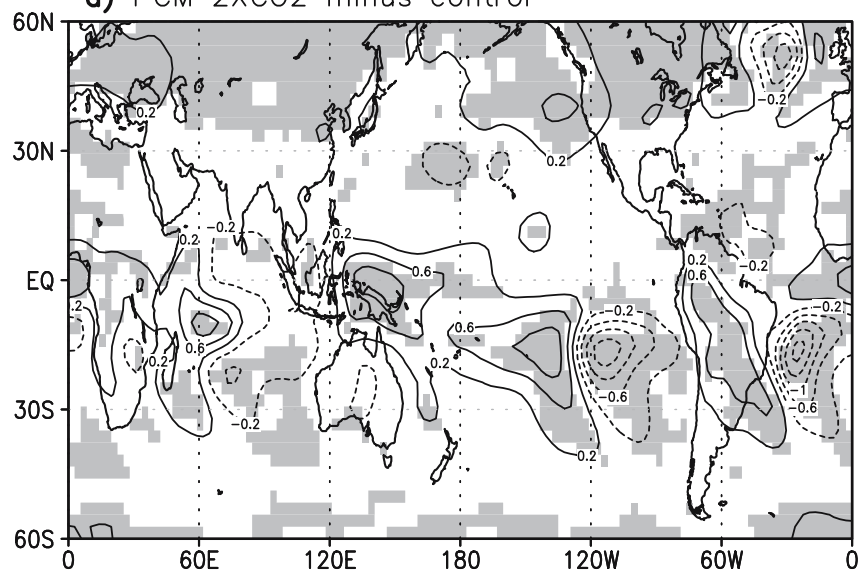

c) $\mathrm{PCM} 4 \times \mathrm{XO} 2$ minus control

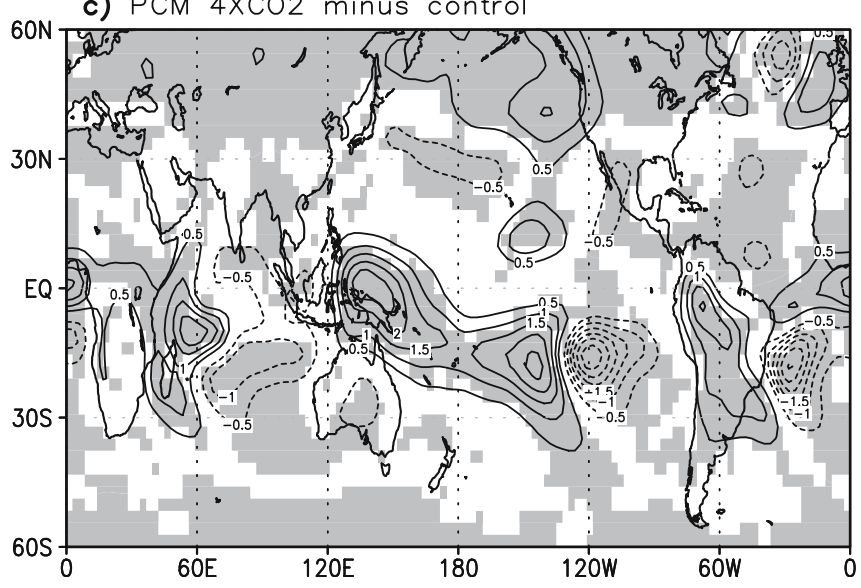

Fig. 9 Change in base state due to increased GHGs as represented by differences in precipitation $\left(\mathrm{mm} \mathrm{day}^{-1}\right)$, spatially smoothed. a PCM $2 \times \mathrm{CO}_{2}$ minus control. b CCSM3 stabilized B1 minus twentieth century stabilization. c PCM $4 \times \mathrm{CO}_{2}$ minus control.

in El Niño amplitude (Meehl et al. 1993; Cubasch et al. 2001) does not hold when the El Niño events decrease in magnitude in a future warmer climate.

The changes of North American temperature anomalies for future El Niño events in Fig. 5 can likely be traced to altered atmospheric teleconnections from the tropics to midlatitudes (Meehl et al. 1993). Figure 7a shows DJF sea level pressure (SLP) anomalies for El Niño events in the PCM control run, and Fig. $7 \mathrm{~b}$ is a similar plot for the twentieth century stabilization experiment from CCSM3. The familiar pattern of an anomalously deeper (negative anomalies) Aleutian Low in the North Pacific has been documented in observations (e.g. Wallace and Gutzler 1981). Figure 7c and d shows the SLP anomalies for $2 \times \mathrm{CO}_{2}$ and B1 El Niño events from PCM and CCSM3, respectively. The anomalous negative SLP differences in the North Pacific are seen to move eastward, and this is seen more clearly with the larger positive radiative forcing for the $4 \times \mathrm{CO}_{2}$ and A1B El Niño events from PCM and CCSM3, respectively, in Fig. 7e and f. There is a notable weakening of the North Pacific teleconnection pattern with higher radiative forcing comparing $2 \times$ to $4 \times \mathrm{CO}_{2}$ El Niño b) $\operatorname{CCSM} 3$ B1 minus 20 thC stabilization

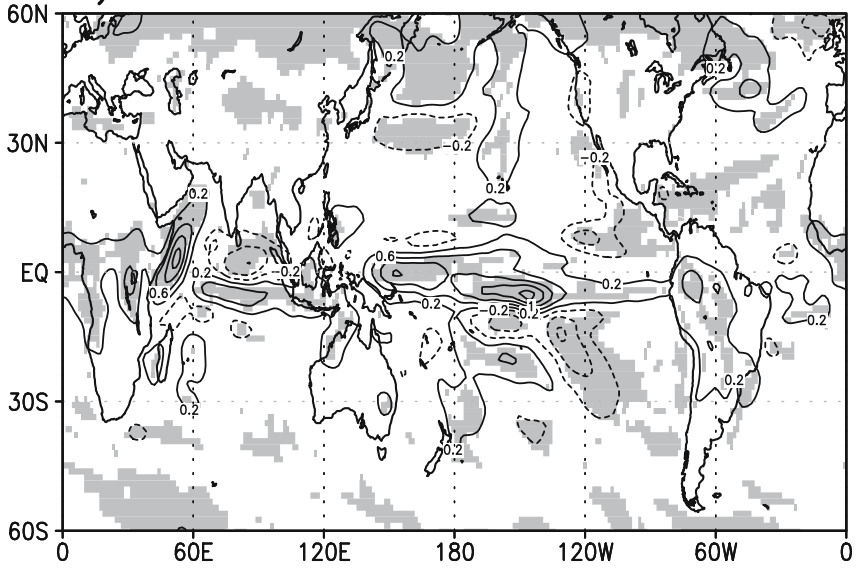

d) $\operatorname{CCSM} 3 \mathrm{~A} 1 \mathrm{~B}$ minus 20 thC stabilization

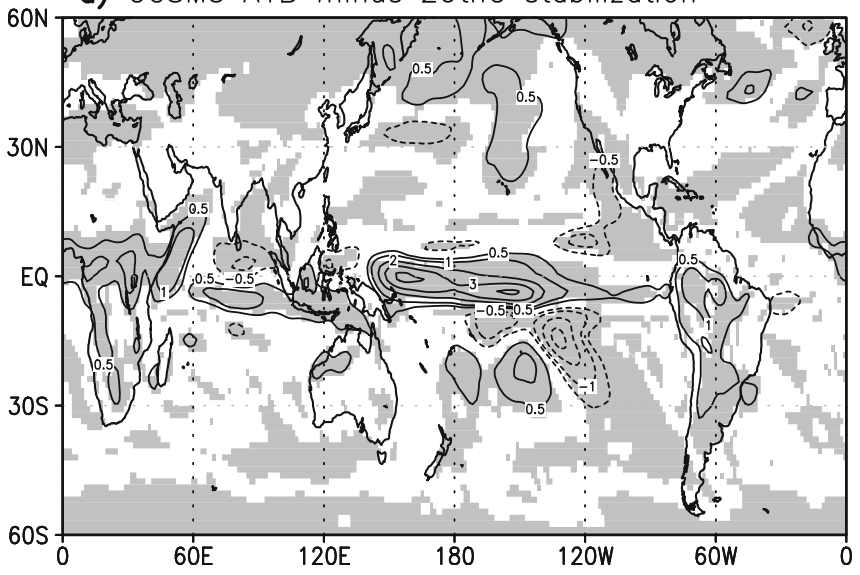

d CCSM3 stabilized A1B minus twentieth century stabilization. Contours are anomalies, and shading represents the $10 \%$ significance level

events from PCM (Fig. 7c, e), and B1 to A1B El Niño events from CCSM3 (Fig. 7d, f). This change in the teleconnection pattern for El Niño events with increased $\mathrm{CO}_{2}$ would affect the surface temperature anomalies in the way described in Fig. 5 such that with progressive increases of positive radiative forcing and the eastward shift and weakening of the negative SLP anomalies in the North Pacific, less anomalously warm air would be advected from the Pacific northeastward to northern North America.

A factor that could contribute to this difference in teleconnections is the reduction in amplitude of the El Niño events themselves (e.g. as discussed in Arblaster et al. 2002). To illustrate this effect, a composite of 42 "strong" El Niño events (Niño3.4 DJF SST anomalies exceeding one standard deviation), and a composite of 49 "moderate" El Niño events (Niño3.4 DJF SST anomalies greater than 0.7 standard deviation but less than 1 standard deviation) are formed from a 400-year segment of the pre-industrial control run (years 600 999), and the associated SLP anomalies are plotted in Fig. $8 \mathrm{a}$ and c. The lower amplitude El Niño events from PCM in Fig. 8c are associated with smaller-amplitude 
Fig. 10 Change in DJF base state due to increased GHGs as represented by differences in $300 \mathrm{hPa}$ streamfunction. a $\mathrm{PCM} 4 \times \mathrm{CO}_{2}$ minus control. b CCSM3 stabilized A1B minus twentieth century stabilization. Contours are anomalies, and shading represents the $10 \%$ significance level. The A1B anomalies for CCSM3 are lower amplitude compared to $\mathrm{PCM}$ due to the smaller forcing $\left(1.89 \times \mathrm{CO}_{2}\right.$ in $\mathrm{CCSM} 3 \mathrm{~A} 1 \mathrm{~B}$ compared to $4 \times \mathrm{CO}_{2}$ for $\left.\mathrm{PCM}\right)$. Units: $\times 10^{6} \mathrm{~m}^{2} \mathrm{~s}^{-1}$

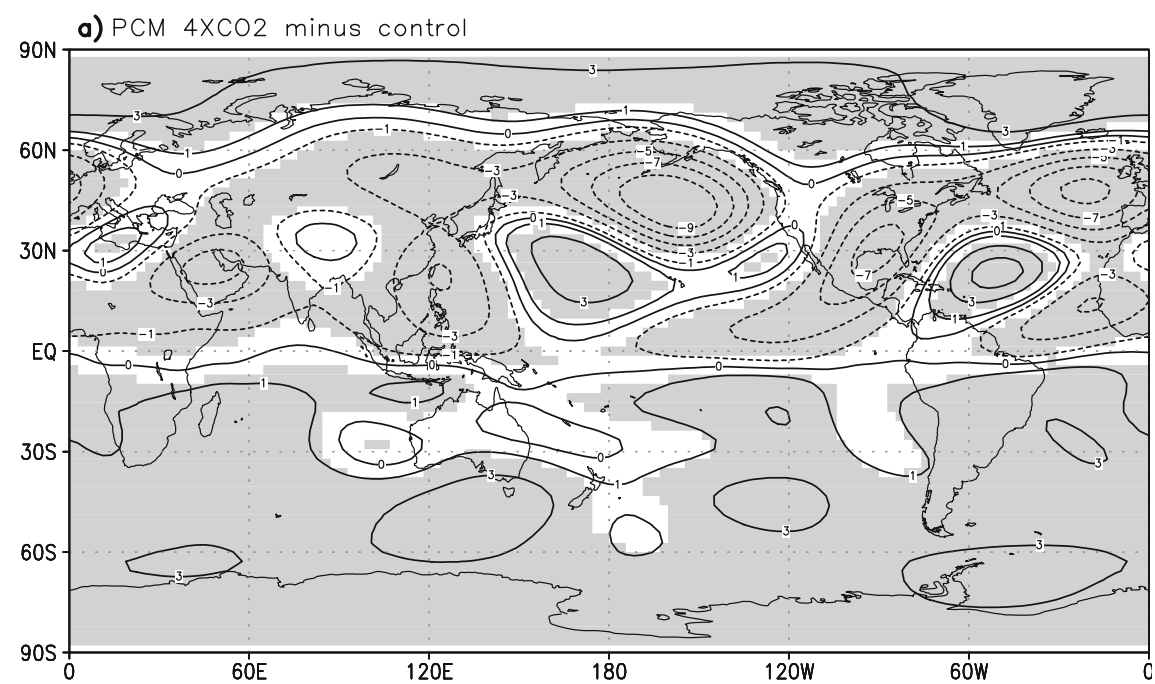

b) $\operatorname{CCSM} 3 \mathrm{~A} 1 \mathrm{~B}$ minus 20 thC stabilization

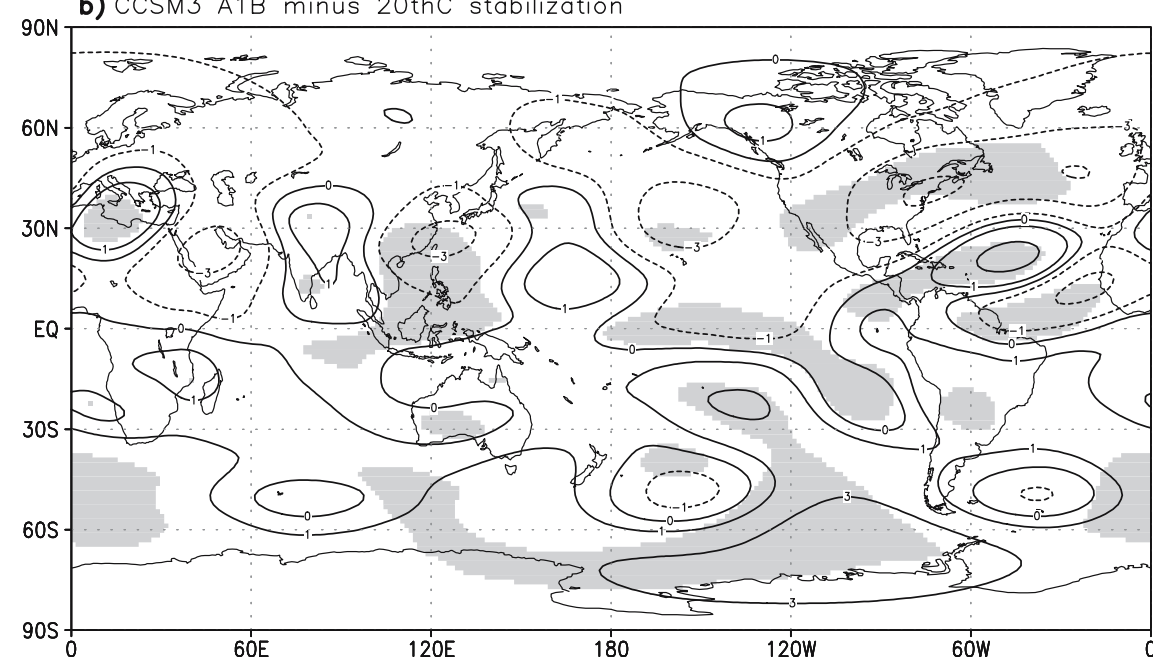

SLP anomalies in the North Pacific (maximum negative SLP anomalies of about $-5 \mathrm{hPa}$ for strong events, and -3 for moderate events).

A similar calculation is performed for the CCSM3 from the last 200 years of the pre-industrial control run (in order to get about the same number of samples as PCM for the CCSM3). The criterion for a strong El Niño event is Niño3.4 DJF SST anomalies exceeding 1.4 standard deviations (this criterion is used in order to obtain about the same numbers of strong and moderate events in CCSM3), which yielded 39 strong events (Fig. 8b), and moderate events were defined as Niño3.4 DJF SST anomalies from 0.8 to 1.4 standard deviations (41 cases in Fig. 8d). As for the PCM, the moderate El Niño event teleconnections to the North Pacific region are smaller than for the strong events, with the maximum negative SLP anomaly in the North Pacific only about $-1.5 \mathrm{hPa}$ in the moderate events, but roughly $-4 \mathrm{hPa}$ for the strong events. Thus the reduction in El Niño amplitude is contributing to the weaker midlatitude teleconnections in these models.

The change in midlatitude teleconnections in El Niño events in a warmer climate could also be related to the midlatitude base state changes from the increases of $\mathrm{CO}_{2}$ (Meehl et al. 1993). Figure 9a and c shows the base state precipitation changes for $2 \times$ and $4 \times \mathrm{CO}_{2}$ from $\mathrm{PCM}$, and Fig. 9b and d for stabilized B1 and A1B from CCSM3. All are characterized by precipitation increases over the central and western tropical Pacific, western tropical Indian Ocean and tropical South America. These changes in tropical precipitation and consequent convective heating anomalies are likely to contribute to the anomalies of DJF $300 \mathrm{hPa}$ streamfunction for $4 \times \mathrm{CO}_{2}$ (Fig. 10a) for PCM, and stabilized A1B for CCSM3 (Fig. 10b) as suggested by the analyses of Meehl et al. (1993) and Selten et al. (2004). The climate change experiments show negative streamfunction difference centers in roughly a wave 5 pattern (e.g. Branstator 2002; Selten et al. 2004) over the northern midlatitudes, with negative centers near the Arabian peninsula, east Asia, central North Pacific, North America, and Atlantic. There are larger magnitude $300 \mathrm{hPa}$ streamfunction anomalies for the $4 \times \mathrm{CO}_{2}$ experiment in Fig. 10a compared to the CCSM3 stabilized A1B experiment in Fig. 10b since the former has about twice the anomalous radiative forcing from increased GHGs 
a) $\operatorname{PSI} 300\left(X 10^{\wedge} 6 \mathrm{~m} * \mathrm{~m} / \mathrm{s}\right)$ 10yr_D150E-100yr_sstclimT42

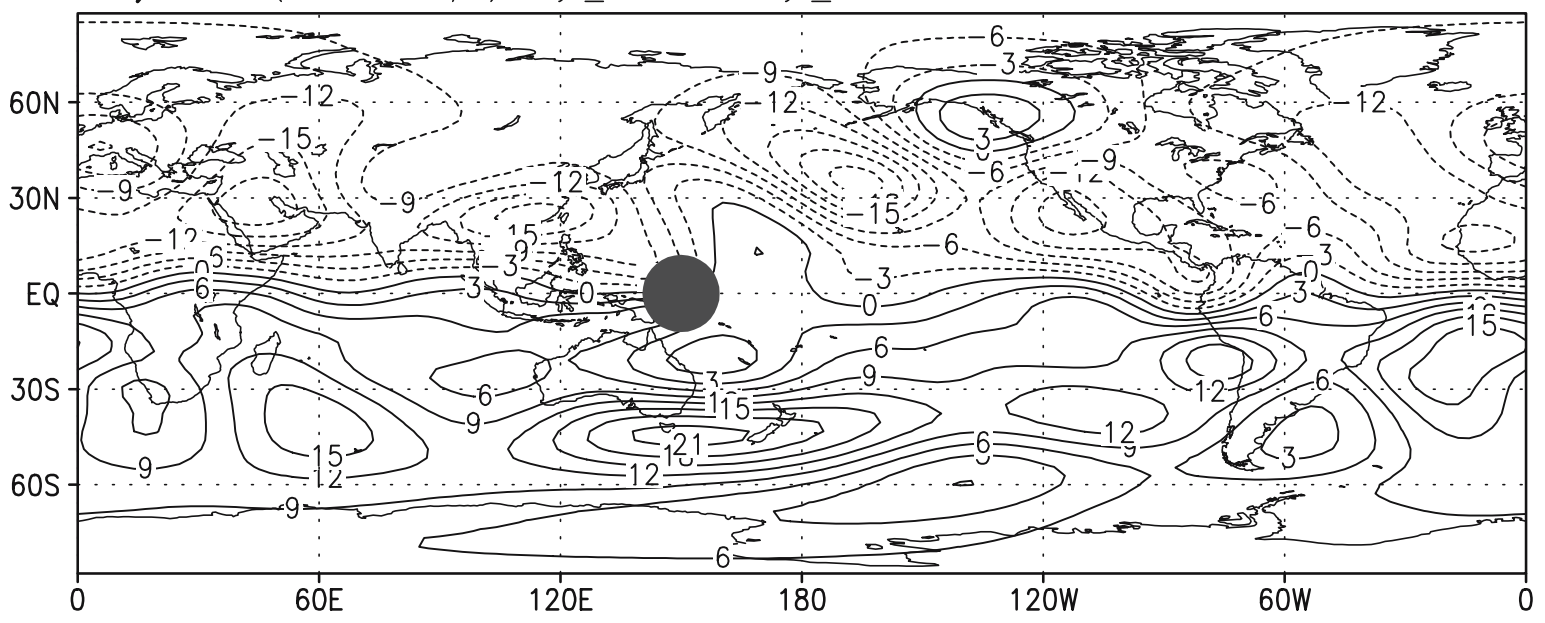

b) $P S(h P a)$ 10yr_D150W-100yr_sstclimT42

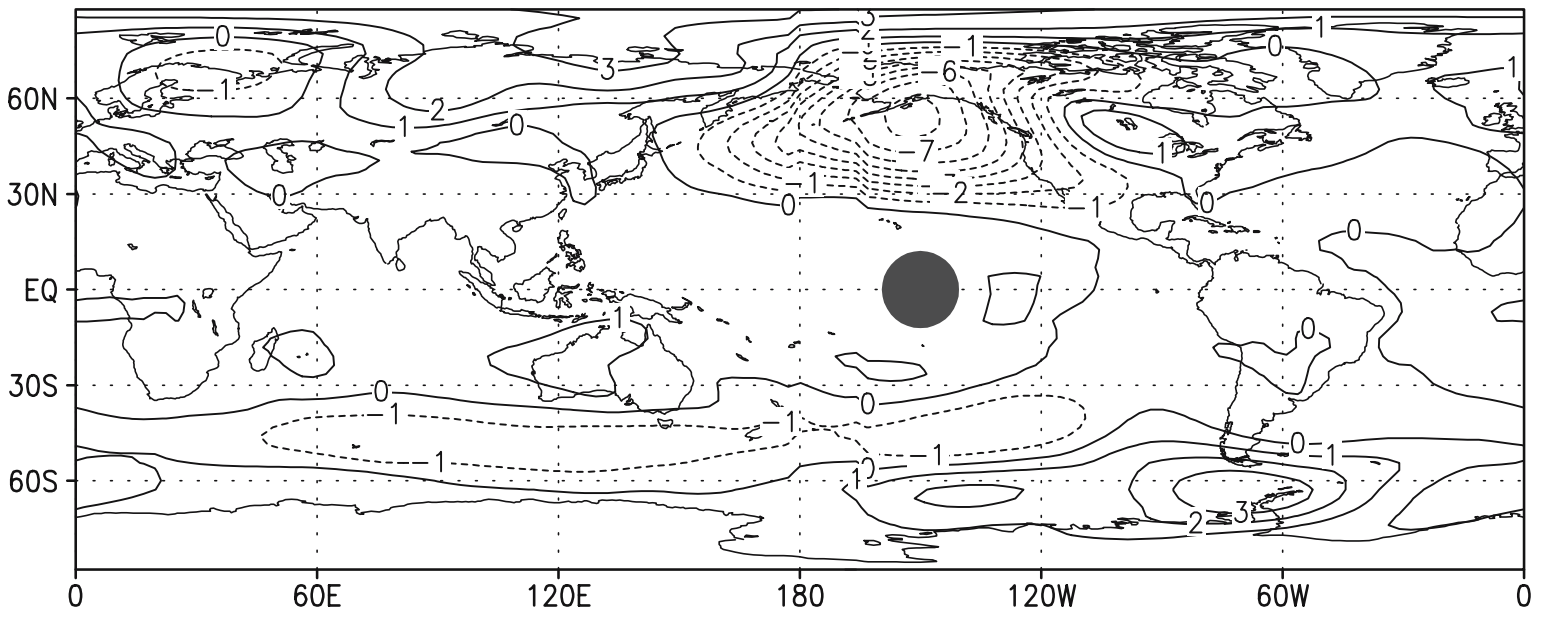

c) $P S(h P a)$ 10yrD150E+D150W-10yr_D150E

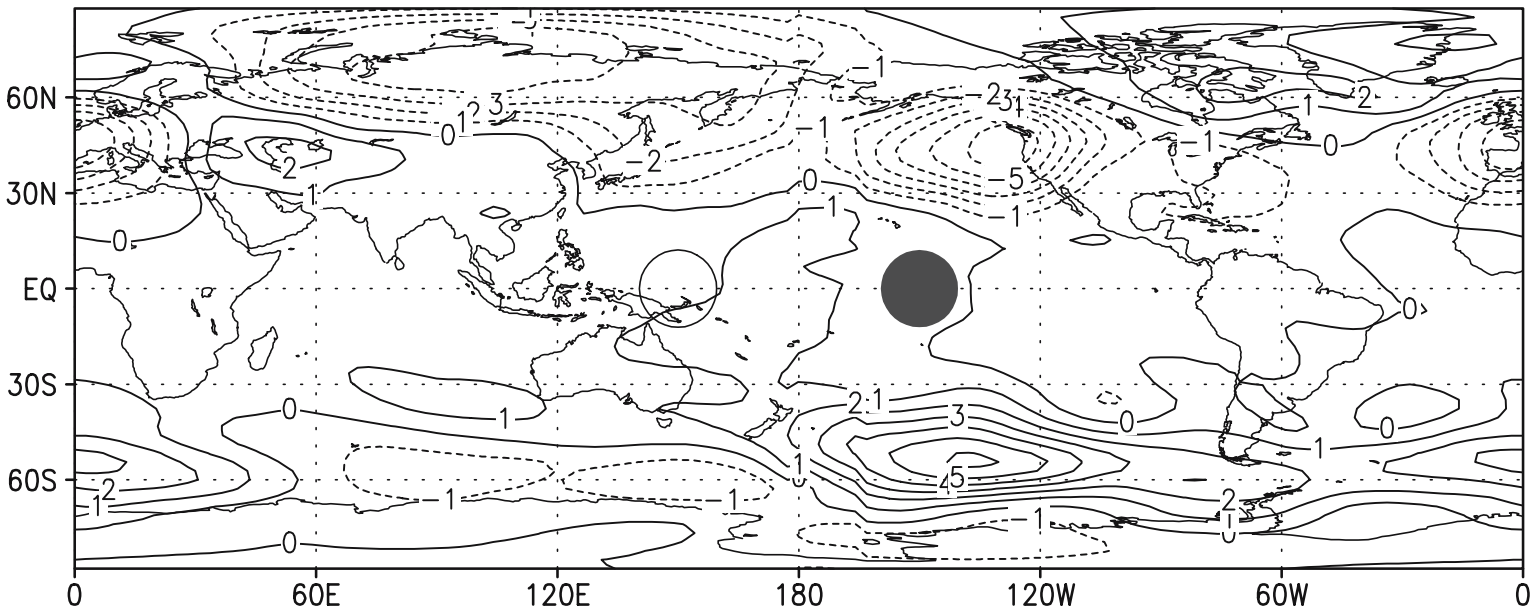

Fig. 11 a Change in DJF base state represented by differences in $300 \mathrm{hPa}$ streamfunction due to an idealized convective heating anomaly centered at $150^{\circ} \mathrm{E}$ in the equatorial western Pacific (shaded circle) meant to be analogous to the change in base state due to increased $\mathrm{CO}_{2}$ in Fig. 9. b DJF SLP anomalies meant to represent teleconnections from an El Niño event associated with an idealized convective heating anomaly centered at $150^{\circ} \mathrm{W}$ in the equatorial eastern Pacific (shaded circle), compare to North Pacific telecon- nections in Fig. 10a and c. c DJF SLP anomalies meant to represent El Niño teleconnections from a combination of convective heating anomalies along the equator, the one at $150^{\circ} \mathrm{W}$ (shaded circle) representing an El Niño event, superimposed on the changed base state representing an increase of $\mathrm{CO}_{2}$ from a second convective heating anomaly at the equator, $150^{\circ} \mathrm{E}$ (open circle), compare to changes in North Pacific teleconnections in Fig. 7 
compared to the latter. From planetary wave propagation theory (Hoskins et al. 1977; Branstator 1983) we know that changes in the midlatitude base state circulation can change the structure of teleconnections from the tropical Pacific to North America, thus possibly contributing to the reduced amplitude surface temperature anomalies over North America in El Niño events with increased GHGs noted in Fig. 5.

To test this possibility, we use a technique similar to Meehl et al. (1993) and specify diabatic heating anomalies in a T42 version of the atmospheric model in CCSM3 (CAM3) with climate SSTs. All results are DJF averages, and we obtain the climatology from a 100 year control run. The specified heating anomaly experiments start on 1 September and are run for 10 years and 4 months. The heating experiments are forced by a steady heat source centered on the equator. In the vertical, the heating $H$ is distributed as $\sin \left(\pi^{*} \sigma\right)$ where $\sigma=$ pressure/surface pressure. In the horizontal, $H$ decreases linearly from a central point until it is zero at a distance of $1,500 \mathrm{~km}$. The central value at $\sigma=0.500$ is $5^{\circ} \mathrm{C} \mathrm{day}^{-1}$. This experimental design is described in Branstator and Haupt (1998) except in that paper it was applied to a different atmospheric model (CCM0). A caveat that must accompany these experiments is that even though the imposed forcing is the same for each equatorial heating experiment, the effective heating anomaly can vary from experiment to experiment. This is because there is a strong positive feedback in the tropics with the imposed heating leading to a coincident precipitation anomaly that often corresponds to an additional heating of similar magnitude to the imposed anomaly.

The atmospheric model is first run for 10 years with a heating anomaly centered at the equator, $150^{\circ} \mathrm{E}$. This roughly corresponds to the area of large amplitude mean increased precipitation in the future climate simulations (Fig. 9). The resulting $300 \mathrm{hPa}$ streamfunction anomaly is shown in Fig. 11a. A similar wave 5 pattern to that seen from the global coupled models with increased GHGs in Fig. 10 is produced, roughly representing the change in base state circulation from the increase in GHGs.

To simulate the teleconnections associated with an El Niño event in this model, we insert an idealized convective heating anomaly at the equator at $150^{\circ} \mathrm{W}$. The sea level pressure pattern produced in this experiment in Fig. 11b shows an anomalously deepened Aleutian Low in the North Pacific. Then, we perform an experiment with the heating anomaly representing an El Niño event at $150^{\circ} \mathrm{W}$, along with the specified heating anomaly on the equator, $150^{\circ} \mathrm{E}$, representing the change in base state due to increased GHGs, and run the model for 10 years. The average change in sea level pressure in this experiment, relative to the experiment in Fig. 11a, is meant to represent the effects on midlatitude teleconnections of an El Niño event superimposed on a mean change in base state from increased GHGs, and is shown in Fig. 11c. Compared to the control run El Niño SLP teleconnection pattern in Fig. 11b, the anomalous low center has weakened and shifted eastward, similar to that seen in the
El Niño events with increased GHGs in the coupled models (Fig. 7). Therefore, both the differences in midlatitude base state circulation associated with increased GHGs, as well as the effects on teleconnections resulting from the lower amplitude of El Niño events in an enhanced GHG environment, appear to contribute to changes in weaker and eastward-shifted midlatitude El Niño teleconnections in a future warmer climate in these models.

\section{Conclusions}

El Niño events in two global coupled climate models are studied for possible future changes in their characteristics with increasing greenhouse gases. Analyses are made of experiments with stabilized $2 \times$ and $4 \times \mathrm{CO}_{2}$ compared to a control run for PCM, and stabilized B1 and A1B scenarios compared to a twentieth century stabilization experiment and transient twenty-first century A2, A1B and B1 experiments in CCSM3. Changes of El Niño magnitude are negligible in the PCM B1 and A1B scenario simulations.

The amplitude of simulated present-day El Niño events in the models is comparable to observed events, with frequencies ranging from 2.5 to 4 years, compared to about 3-7 years in observations. The El Niño events in PCM and CCSM3 show both SST and thermocline modes, with the SST modes more predominant. El Niño frequency in these experiments does not change appreciably with increased positive radiative forcing. The amplitude of Niño3.4 SST standard deviations decreases somewhat with $2 \times \mathrm{CO}_{2}$ in PCM and the stabilized B1 scenario in CCSM3, and even more with $4 \times \mathrm{CO}_{2}$ in PCM and the stabilized A1B scenario in CCSM3.

There is significant low frequency variability of $\mathrm{El}$ Niño event amplitude in a 1,200 year control run of PCM and a 500 year control run with CCSM3, and the reduced amplitude of Niño3.4 SSTs in the $2 \times \mathrm{CO}_{2}$ run in PCM and the stabilized B1 experiment in CCSM3 is close to the range of the models' natural variability. But the decrease in El Niño amplitude with larger positive radiative forcing for $4 \times \mathrm{CO}_{2}$ in $\mathrm{PCM}$, and the stabilized A1B scenario for CCSM3, is well outside the range of inherent low frequency El Niño variability, and the reductions in amplitude for these experiments are statistically significant. However, other studies surveying a wider range of models show a great deal of model dependence of such results (e.g. Collins 2000b; Merryfield 2006; Guilyardi 2005; van Oldenborgh et al. 2005).

Analysis of multi-ensemble member transient B1, A1B and A2 scenario experiments with PCM and CCSM3 (not shown) show a similar tendency for decreased El Niño amplitude with increased GHGs, but none of these changes are statistically significant suggesting that such changes of El Niño would be difficult to detect over the course of the twenty-first century, and may only emerge farther into the future with much larger forcing. 
These reductions of El Niño amplitude in the two models are traced to temperature differences in the upper equatorial Pacific Ocean. The warming throughout the upper ocean is not uniform, with greater warming at the surface and below the thermocline in both models. The warmer and more diffuse thermocline, partially due to a decrease in strength of the STCs in the Pacific, contributes to reducing El Niño amplitude.

Even though these El Niño anomalies are superimposed upon warmer base state SSTs, precipitation anomalies in the tropics are not intensified in the future El Niño events because El Niño amplitudes decrease with greater positive radiative forcing. Previous studies that showed such an intensification of El Niño precipitation anomalies in a future warmer climate assumed little change in El Niño amplitude. In the present experiments, the reduction in El Niño amplitude plays a larger role than the warmer base state on affecting changes in tropical precipitation anomalies.

There are changes in surface temperature anomalies associated with future El Niño events that are particularly notable and significant over North America. The anomalously warmer conditions over Alaska and northern Canada, and cooler temperatures over the southeastern US, weaken during El Niño events with increased GHGs. This is attributed to a change in midlatitude teleconnections, with the anomalously deepened Aleutian low weakening and shifting eastward in future warmer climates. These changes in teleconnections are traced to a change in base state midlatitude circulation likely associated with convective heating anomalies in the tropical Pacific in the warmer climate. This is verified in sensitivity experiments with a version of the atmospheric model (CAM3 as in CCSM3) with specified heating anomalies. Weaker teleconnections to midlatitudes associated with the future lower amplitude El Niño events in the models also contribute to the modifications in midlatitude anomalies for El Niño events during enhanced GHG conditions.

Though we have identified physical processes that would lead to lower amplitude El Niño events in these two particular models, there are indications that future changes of El Niño could be quite model-dependent. Merryfield (2006) and Guilyardi (2005) analyze a multimodel dataset and show decreases of El Niño amplitude in some models, but increases or little change in others. The latter study addresses the nature of some of the physical processes operating in these various models that produce different El Niño responses with increased GHGs, and outlines some possible reasons for the model-dependence of the results.

In any case, it appears that there is currently no definitive answer to the question of what will happen to El Niño in the future. But we now have much more information from AOGCMs regarding the role of inherent natural variability, base-state dependent changes on tropical and midlatitude teleconnections, and some good physical reasons for why the models produce the range of results. The present study illustrates some of these processes for two models, and suggests future analyses for more models.

Acknowledgements The authors acknowledge Robert Tomas and Aixue $\mathrm{Hu}$ for their valuable contributions to this analysis, and Mat Collins and Eric Guilyardi for constructive and useful reviews of the manuscript. This work was supported in part by the Office of Biological and Environmental Research, U.S. Department of Energy, as part of its Climate Change Prediction Program, and by the Weather and Climate Impact Assessment Initiative at the National Center for Atmospheric Research. The National Center for Atmospheric Research is sponsored by the National Science Foundation.

\section{References}

Achutarao K, Sperber K (2006) ENSO simulation in coupled ocean-atmosphere models: are the current models better? Clim Dyn (in press)

Ammann C, Meehl GA, Washington WM, Zender C (2003) A monthly and latitudinally varying volcanic forcing dataset in simulations of twentieth century climate. Geophys Res Lett 30 (12):1657, doi:10.1029/2003GL016875RR

Arblaster JM, Meehl GA (2006) Contribution of various external forcings to trends in the Southern Annular Mode. J Clim (in press)

Arblaster JM, Meehl GA, Moore A (2002) Interdecadal modulation of Australian rainfall. Clim Dyn 18:519-531

Branstator G (1983) Horizontal energy propagation in a barotropic atmosphere with meridional and zonal structure. J Atmos Sci 40:1689-1708

Branstator G (2002) Circumglobal teleconnections, the jet stream waveguide, and the North Atlantic oscillation. J Clim 15:1893-1910

Branstator G, Haupt S (1998) An empirical model of barotropic atmospheric dynamics and its response to tropical forcing. J Clim 11:2645-2667

Capotondi A et al (2006) Spatial and temporal structure of ENSO in 20th century coupled simulations. Ocean Model (in press)

Chen X, Kimoto M, Takahashi M (2005) Changes in ENSO in response to greenhouse warming as simulated by the CCSR/ NIES/FRCGC coupled GCM. SOLA 1:149-152

Collins M (2000a) Understanding uncertainties in the response of ENSO to greenhouse warming. Geophys Res Lett 27:3509-3513

Collins M (2000b) The El Niño Southern Oscillation in the second Hadley centre coupled model and its response to greenhouse warming. J Clim 13:1299-1312

Collins WD et al (2006) The community climate system model: CCSM3. J. Clim (in press)

Cubasch U, Meehl GA, Boer GJ, Stouffer RJ, Dix M, Noda A, Senior CA, Raper S, Yap KS (2001) Projections of future climate change. In: Houghton JT., Ding Y, Griggs DJ, Noguer M, van der Linden P, Dai X, Maskell K, Johnson CI (eds) Climate change 2001: the scientific basis. Contribution of working group I to the 3rd assessment report of the intergovernmental panel on climate change, Cambridge University Press, Cambridge, pp 525-582

Dai A, Meehl GA, Washington WM,Wigley TML (2001) Ensemble simulations of 21 st century climate changes: Business as usual vs. $\mathrm{CO}_{2}$ stabilization. Bull Am Meteorol Soc 82:2377-2388

Dai A, Hu A, Meehl GA, Washington WM, Strand WG (2005) Atlantic thermohaline circulation in a coupled general circulation model: unforced variations vs. forced changes. J Clim 18:3270-3293

Deser C, Capotondi A, Saravanan R, Phillips A (2006) Tropical Pacific and Atlantic climate variability in CCSM3. J Clim (in press)

Dickinson RE, Oleson KW, Bonan GB, Hoffman F, Thornton P, Vertenstein M, Yang Z-L, Zeng X (2006) The community land model and its climate statistics as a component of the community climate system model. J Clim (in press) 
Guilyardi E et al (2004) Representing El Niño in coupled oceanatmosphere GCMs: the dominant role of the atmospheric component. J Clim 17:4623-4629

Guilyardi E (2005) El Niño-mean state-seasonal cycle interactions in a multi-model ensemble. Clim Dyn DOI 10.1007/s00382-0050084-6

Holland MM, Bitz CM, Hunke EC, Lipscomb WH, Schramm JL (2006) Influence of the sea ice thickness distribution on polar climate in CCSM3. J Clim (in press)

Hoskins BJ, Simmons AJ, Andrews DC (1977) Energy dispersion in a barotropic atmosphere. Quart J Roy Meteor Soc 103:553-567

Joseph R, Nigam S (2006) ENSO evolution and teleconnections in IPCC 20th century climate simulations: Realistic representation? J Clim (in press)

Kaplan A, Kushnir Y, Cane MA, Blumenthal MB (1997) Reduced space optimal analysis for historical datasets: 136 years of Atlantic sea surface temperatures. J Geophys Res 102:27835-27860

Kleeman R, McCreary JP, Klinger BA (1999) A mechanism for the decadal variation of ENSO. Geophys Res Lett 26:1743-1747

Knutson TR, Manabe S (1998) Model assessment of decadal variability and trends in the tropical. Pacific Ocean J Clim $11: 2273-2296$

Latif M et al (2001) ENSIP: the El Niño simulation intercomparison project. Clim Dyn 18:255-276

van Loon H, Meehl GA, Milliff R (2003) The Southern Oscillation in the early 1990s. Geophys Res Lett 30:1478, doi:10.1029/ 2002GL016307

McPhaden MJ, Zhang D (2002) Slowdown of the meridional overturning circulation in the upper Pacific Ocean. Nature 415:603-608

Meehl GA (1987) The annual cycle and interannual variability in the tropical Pacific and Indian Ocean regions. Mon Weather Rev 115:27-50

Meehl GA, Arblaster JM (2003) Mechanisms of projected future changes in south Asian monsoon precipitation. Clim Dyn 21:659-675

Meehl GA, Branstator GW, Washington WM (1993) Tropical Pacific interannual variability and $\mathrm{CO}_{2}$ climate change. J Clim 6:42-63

Meehl GA, Gent P, Arblaster JM, Otto-Bliesner B, Brady E, Craig A (2001) Factors that affect amplitude of El Niño in global coupled climate models. Clim Dyn 17:515-526

Meehl GA, Washington WM, Wigley TML, Arblaster JM, Dai A (2003) Solar and greenhouse gas forcing and climate response in the 20th century. J Clim 16:426-444

Meehl GA, Washington WM, Ammann C, Arblaster JM, Wigley TML, Tebaldi C (2004a) Combinations of natural and anthropogenic forcings and 20th century climate. J Clim 17:3721-3727

Meehl GA, Washington WM, Ammann C, Arblaster JM, Wigley TML, Tebaldi C (2004b) Combinations of natural and anthropogenic forcings and 20th century climate. J Clim $17: 3721-3727$
Meehl GA, Washington WM, Collins WD, Arblaster JM, Hu A, Buja LE, Strand WG, Teng H (2005) How much more global warming and sea level rise? Science 307:1769-1772

Meehl GA, Washington WM, Santer BD, Collins WD, Arblaster JM, Hu A, Lawrence D, Teng H, Buja LE, Strand WG (2006) Climate change in the 20th and 21st centuries and climate change commitment in the CCSM3. J Clim (in press)

Merryfield W (2006) Changes to ENSO under $\mathrm{CO}_{2}$ doubling in the IPCC AR4 coupled climate models. J Clim (in press)

Nonaka M, Xie S-P, McCreary JP (2001) Decadal variations in the subtropical cells and equatorial Pacific SST. Geophys Res Lett 29:1116, doi: 10.1029/2001GL013676

van Oldenborgh G, Philip S, Collins M (2005) El Niño in a changing climate: A multi-model study. Ocean Sci Discuss 2:267-29

Ropelewski CE, Halpert MS (1987) Global and regional scale precipitation patterns associated with the El Niño/Southern Oscillation. Mon Weather Rev 115:1606-1626

Santer BD, Wehner MF, Wigley TML, Sausen R, Meehl GA, Taylor KE, Ammann C, Arblaster JM, Washington WM, Boyle JS, Bruggemann W (2003a) Contributions of anthropogenic and natural forcing to recent tropopause height changes. Science 301:479-483

Santer BD, Wigley TML, Meehl GA, Wehner MF, Mears C, Schabel M, Wentz FJ, Ammann C, Arblaster JM, Bettge T, WashingtonWM, Taylor KE, Boyle JS, Bruggemann W, Doutriaux C (2003b) Influence of satellite data uncertainties on the detection of externally-forced climate change. Science 300:1280-1284

Selten FM, Branstator GW, Dijkstra HA, Kliphuis M (2004) Tropical origins for recent and future Northern Hemisphere climate change. Geophys Res Lett 31:L21205, doi:10.1029 2004GL020739

Solomon A, McCreary Jr JP, Kleeman R, Klinger BA (2003) Interannual and decadal variability in an intermediate coupled model of the Pacific region. J Clim 16:383-405

Timmermann A (1999) Detecting the nonstationary response of ENSO to greenhouse warming. J Atmos Sci 56:2313-2325

Timmermann A, Oberhuber J, Bacher A, Esch M, Latif M, Roeckner E (1999) Increased El Niño frequency in a climate model forced by future greenhouse warming. Nature 398:694-696

Wallace JM, Gutzler DS (1981) Teleconnections in the geopotential height field during the Northern Hemisphere winter. Mon Weather Rev 109:784-812

Washington WM, Weatherly JW, Meehl GA, Semtner Jr AJ, Bettge TW, Craig AP, Strand Jr. WG, Arblaster JM, Wayland VB, James R, Zhang Y (2000) Parallel climate model (PCM) control and transient simulations. Clim. Dyn 16:755-774

Yasunari T (1991) "The monsoon year"-a new concept of the climatic year in the tropics. Bull Am Meteorol. Soc 72:1331-1338 